\section{Policy Research Working Paper}

Dollarization and Semi-Dollarization in Ecuador

Paul Beckerman

\section{WPS 2643}

2643
In January 2000 Ecuador announced that it would dollarize fully, in response to an unprecedented crisis encompassing recession. widespread bank failures, and incipient hyperinflation. The crisis had intensified since early 1998, when a combination of external and climatic shocks set it off. The economy's partial dollarization made the crisis far worse than it would otherwise have been. The move to full dollarization is perhaps best understood as a structural reform to end an unstable dual-currency system.

The World Bank

Latin America and the Caribbean Region

Economic Policy Sector Unit

July 2001 


\section{Summary findings}

Over the 1980s and 1990s, GDP growth had stagnated because on account of oil export price volatility and natural disasters; the sacrifice of capital formation to heavy external public debt service; and incomplete, uneven structural reform. The exchange rate depreciation that proved continually necessary to sustain the net-export surplus and limit external debt accumulation induced Ecuadorians to dollarize spontaneously.

The 1998 shocks affected real economic activityhence bank loan portfolios, and widened the fiscal and current account deficits. The external imbalance led to exchange rate depreciation. Dollar-denominated bank loans whose borrowers lacked dollar income increasingly turned non-performing. At the same time, the depreciation swelled the local currency value of dollar deposit liabilities. Many depositors, fearing that banks had become unsafe, withdrew, and over 1999 the Central Bank had to provide banks massive liquidity support. By year's end the resulting monetary issue led to the exchange rate collapse and incipient hyperinflation that forced the move to full dollarization.

Ecuador's Central Bank will continue operating, using its foreign exchange holdings to carry out limited liquidity management and lender-of-last-resort activities. Ecuador's public accounts and banking system remain vulnerable to commodity-price and natural shocks. Exchange rate adjustment and monetary expansion are no longer available, however, to manage the external accounts, accommodate the public deficit, or: assist failing banks. Further structural reform remains essential to assure fiscal discipline and banking system safety.

This paper-a product of the Economic Policy Sector Unit, Latin America and the Caribbean Region-is part of a larger effort in the region to understand the sources of macroeconomic instability and the implications of currency board arrangements and dollarization. Copies of the paper are available free from the World Bank, $1818 \mathrm{H}$ Street NW, Washington, DC 20433. Please contact Patricia Chacon Holt, Room 18-170, telephone 202-473-7707, email address pholt@worldbank.org. Policy Research Working Papers are also posted on the Web at http://econ.worldbank.org. The author may also be contacted at pbeckerman@alum.mit.edu.July 2001. (38 pages)

The Policy Research Working Paper Series disseminates the findings of work in progress to encourage the exchange of ideas about development issues. An objective of the series is to get the findings out quickly, even if the presentations are less than fully polished. The papers carry the names of the authors and should be cited accordingly. The findings, interpretations, and conclusions expressed in this paper are entirely those of the authors. They do not necessarily represent the view of the World Bank, its Executive Directors, or the countries they represent. 


\title{
DOLLARIZATION AND SEMI-DOLLARIZATION IN ECUADOR
}

\author{
Paul Beckerman*
}

Summary. In January 2000 Ecuador announced that it would dollarize fully, in response to an unprecedented crisis encompassing recession, widespread bank failures, and incipient hyperinflation. The crisis had intensified since early 1998, when a combination of external and climatic shocks set it off. The economy's semi-dollarization made the crisis far worse than it would otherwise have been. The move to full dollarization is perhaps best understood as a structural reform to end an unstable dual-currency system. Over the 1980s and 1990s, GDP growth had stagnated on account of oil-export price volatility and natural disasters; the sacrifice of capital formation to heavy external public debt service; and incomplete, uneven structural reform. The exchange-rate depreciation that proved continually necessary to sustain the net-export surplus and limit external-debt accumulation induced Ecuadorians to dollarize spontaneously. The 1998 shocks affected real economic activity, hence bank loan portfolios, and widened the fiscal and currentaccount deficits. The external imbalance led to exchange-rate depreciation. Dollardenominated bank loans whose borrowers lacked dollar income increasingly turned nonperforming, while depreciation swelled the local-currency value of dollar deposit liabilities. Many depositors, fearing that banks were unsafe, withdrew. Over 1999 the Central Bank had to provide banks massive liquidity support. By the year's end the resulting monetary issue led to the exchange-rate collapse and incipient hyperinflation that forced the move to full dollarization. Ecuador's Central Bank will continue in operation, using its foreign-exchange holdings to carry out limited liquidity-management and lender-of-last-resort activities. Ecuador's public accounts and banking system remain vulnerable to commodity-price and natural shocks. Exchange-rate adjustment and monetary expansion are no longer available, however, to manage the external accounts, accommodate the public deficit or assist failing banks. Further structural reform remains essential to assure fiscal discipline and banking-system safety.

References and statistical tables follow the main text.

*World Bank. The writer thanks Hana Brixi, Sara Calvo, Krishna Challa, Peter Dohlman, Mauricio Carrizosa, Hernán Cortés Douglas, James Hanson, Cláudia Paz, and participants in a joint workshop of the World Bank's Quality of Fiscal Adjustment and Managing Capital Mobility Thematic Groups on October 3, 2000 for comments on earlier drafts. The writer alone is responsible for errors of fact and judgment. Views expressed here do not necessarily reflect those of the World Bank nor any other institutions with which this writer has been associated. 



\section{Introduction}

On January 9,2000, in the midst of a deep recession and with its exchange rate in apparent free fall, Ecuador's Government announced that it would fix the exchange rate and submit legislation to the Congress to dollarize the economy. Ecuador's sucre, floating since mid-February 1999, had lost two thirds of its U.S.-dollar value over 1999, then a quarter of its end-1999 value over the first week of 2000. Real GDP had fallen 7.3 per cent in 1999 . Bank credit operations were virtually suspended, and a liquidity crisis loomed as banks prepared for March 2000, when time deposits, frozen in March 1999 until one year past their original maturity dates, were to begin being released. On January 21, the President, who had been elected in mid-1998 to a five-year term, was forced from office because of widespread dissatisfaction with the economy and some opposition to dollarization. The following day, after some Army officers and leaders of indigenous people's organizations attempted unsuccessfully to seize power; the Vice President assumed the presidency in accord with the Constitution. Despite the controversy, the new Government pressed ahead with dollarization, drafting the legislation and submitting it to the Congress. The Congress approved it rapidly - partly because some parties abstained from the debate -- and in early March the President signed it into law. Within months the Central Bank purchased virtually all sucre issues and the dollar was fully accepted as the legal currency unit.

This paper discusses Ecuador's "leap" from incipient hyperinflation to dollarization. Section 2 sets out the background, reviewing (a) the economy's vulnerability to natural shocks and export volatility; (b) consequences for growth and exchange-rate stability of the adjustment over the 1980s and 1990s to cope with external debt; and (c) lagging structural reform. Section 3 focuses on causes and implications of the economy's "semi-dollarization" before 2000. Section 4 reviews the evolution of the 1998-9 "pre-dollarization" crisis. Section 5 describes Ecuador's dollarization approach, which maintains a "central bank" with limited liquidity-management and lender-of-lastresort functions. Section 6 discusses transition issues, including (a) release of time deposits frozen in March 1999; (b) the price-level increase caused by the sucre's undervaluation on conversion; and (c) "convergence" of costs and prices. Section 7 discusses longer-term policy implications, and Section 8 offers concluding observations.

Since 1982, exchange-rate instability had complicated financial planning, discouraged investment and production, generated inflationary pressure, and haphazardly redistributed wealth and income. It also encouraged spontaneous dollarization: by the 1990 s the economy was operating in two units of account with an unstable exchange rate. This complicated private- and public-sector financial management as well as monetary and exchange-rate policy. Semi-dollarization figured centrally in the evolution of the pre-dollarization crisis. A coincidence of exogenous shocks in 1998 widened the currentaccount deficit, pressuring the exchange rate to depreciate. The shocks themselves affected banks' loan quality, but the banks' semi-dollarization meant that the exchangerate slide significantly worsened the damage. Although the banks had always been careful to keep dollar liabilities matched by dollar assets, too many of their dollar 
borrowers were themselves unmatched, with sucre earnings backing dollar obligations. Exchange-rate depreciation therefore increased banks' non-performing loans and diminished cash inflows. Fearing for bank safety, depositors began withdrawing, intensifying banks' illiquidity. The authorities' efforts to cope produced further complications. In December 1998 they extended a government guarantee to all deposits. In March 1999 they froze deposits for a year, then tried to undo the damage this caused by gradually unfreezing, leading to deposit withdrawals. The monetary authority had to provide liquidity credit to prevent bank failures. Over 1999 the monetary base more than doubled, leading to the exchange-rate collapse at the year's end. The authorities then had little choice: had they not dollarized, hyperinflation was inevitable.

Even with dollarization, the Central Bank will maintain a role. Its relatively large dollar holdings will afford it some scope to influence liquidity conditions and to assist banks undergoing temporary illiquidity. The authorities hope this will suffice to sustain public confidence. In many respects it will work like a currency board (see Baliño, Enoch et al 1997). As Section 5 explains, the dollarized Central Bank will (i) issue small-denomination coins, (ii) hold commercial banks' reserve deposit accounts, (iii) maintain the Treasury's deposit account, and (iv) carry on limited liquiditymanagement and lender-of-last-resort functions. Its foreign-exchange holdings (a large proportion of which are borrowed) will back the liabilities arising in these activities. Important hazards remain. The banks and the public sector remain vulnerable to export volatility, seismic and weather hazards, and evolving international financial conditions. Having lost the option of inflationary accommodation, the public sector could come to rely even more than before on external or domestic borrowing to cope with contingencies, a troubling concern because the public-debt burden remains excessive.

One claim made for dollarization is that it has set a political context favorable to long-overdue structural reform. The dollarization and follow-up legislation incorporated some reform, but far more remains necessary. Structural reform must advance, inter alia, to mitigate the dangers of the "contingencies" to which the economy remains exposed. This is especially true for the banking system. As they reconstitute it, the authorities must find ways to enable it to operate safely in an "accident-prone" economy. One broad approach would be to "internationalize" banking operations - to bring world-dimension capital bases effectively behind Ecuadorian banks' risk exposure.

\section{The background to dollarization, $1970-2000$}

To understand why Ecuador's economy proved so vulnerable to the exogenous shocks of 1998 , it is helpful to trace the chain of events that led from the debt crisis of the early 1980 s to he economy's semi-dollarization. This is the purpose of this section and Section 3 immediately following.

Ecuador's GDP grew more slowly than the public external debt and at about the same rate as the population over the 1980s and 1990s (see Figure 1). Per-capita real private consumption remained essentially unchanged. Over the 1990 s poverty incidence worsened, partly because inadequate and volatile public revenue and the debt-service 
burden together constrained government provision of health, education and social-welfare services. The measured (consumption-based) poverty incidence rose from 34 per cent in 1995 to 46 per cent in 1998. Extreme poverty (food consumption below minimum nutrition standards) rose from 15 to 17 per cent. Preliminary data suggest that these indicators worsened sharply during 1999 , the worst crisis year. Causes of the poor economic performance through the 1980s and 1990s included (a) the economy's vulnerability to "contingencies"; (b) the macroeconomic adjustment forced by the external-debt crisis of the early 1980 s, and (c) the incompleteness and unevenness of structural reform in the public and financial sectors. This section discusses these in turn. ${ }^{1}$

Figure 1. Ecuador: Per-capita real GDP, real private consumption, and year-end per-capita public external debt in 1999 U.S. dollars and prices, ${ }^{*}$ 1972-2000

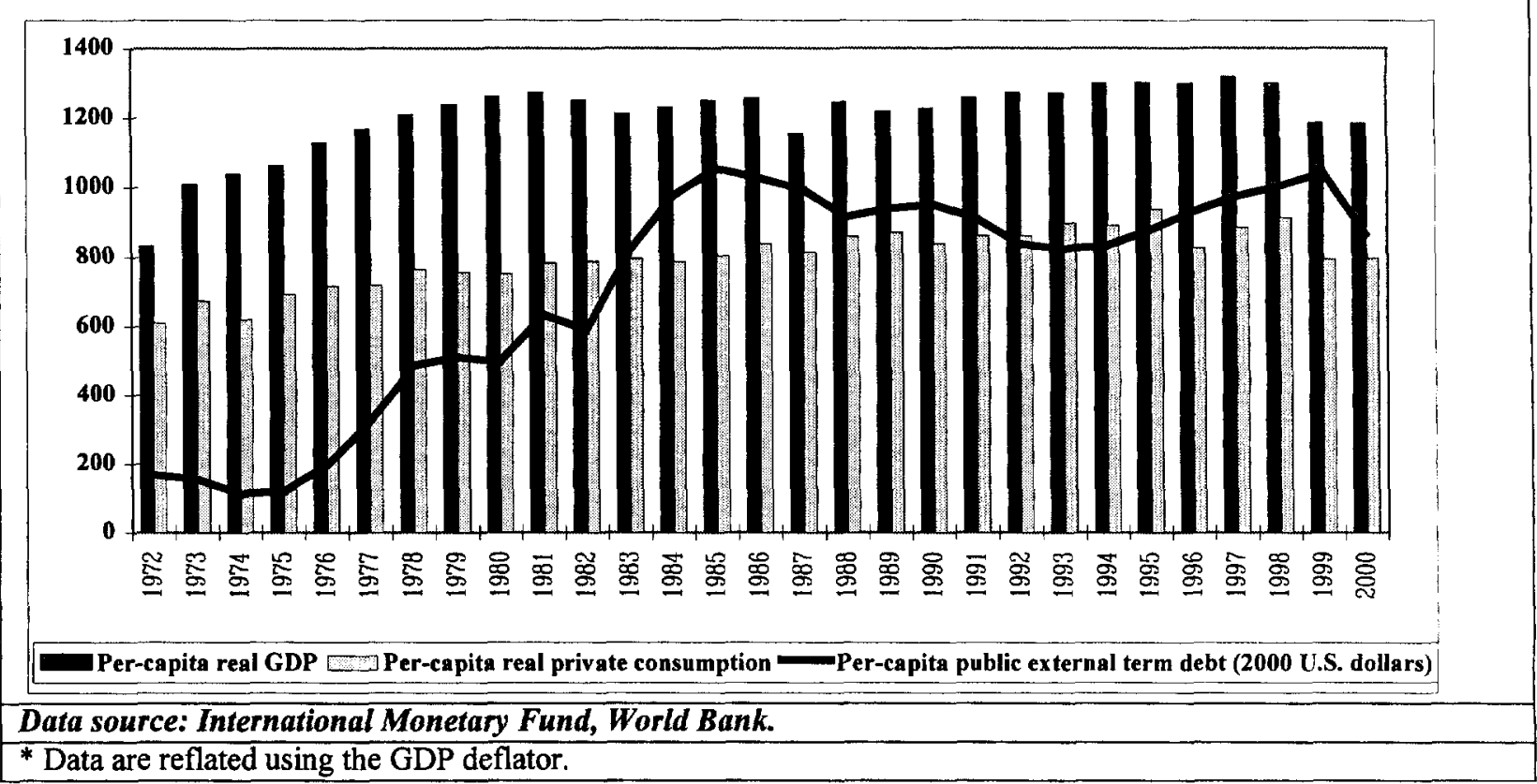

(a) "Contingency": Over the 1980s and 1990s, natural and external shocks subjected the economy to volatility and natural risks. Ecuador possesses a rich resource endowment, but is vulnerable to crop disease, earthquakes, volcanoes, and cycles of drought and excess rain. El Niño rainfall caused heavy damage in 1975, 1983 and 1998. A 1987 earthquake stopped oil exports for nearly half a year. Drought has been a recurring problem, affecting agricultural production and electricity generation in several recent years. (Growing populations and infrastructure accumulation make natural disasters costlier as time passes.) Throughout Ecuador's history, dependence on primary commodity exports sold in volatile world markets and subject to diseases -- including

\footnotetext{
${ }^{1}$ Conceptually, contingency destabilized the economy's production-possibility frontier; the macroeconomic adjustment forced the economy's consumption and investment point inward; and the inadequacy of structural adjustment left the economy within its frontier.
} 
cacao, bananas, sea products, and oil -- has brought about boom-and-bust cycles. ${ }^{2}$ In recent years, growing integration with world financial markets has increased Ecuador's vulnerability to shifting cross-border financial flows. During 1993 and 1994, for example, a change in exchange-rate policy and high domestic interest rates induced significant short-term financial inflows; during 1995, however, these flows reversed, worsening the economic downturn that took place that year. During 1998 and 1999, retraction of trade-credit lines worsened the banking crisis (see Section 4).

Ecuador is hardly alone in having to cope with exogenous shocks. Many other economies depend on commodity exports, face natural hazards, and cope with volatile financial flows. Ecuador does face an unusually wide range of contingencies, however, and the economy's small size and dependence on a few volatile export markets leave it especially vulnerable. The "bust" phases and the risks they pose for capital formation have been a standing constraint to economic growth.

(b) Macroeconomic adjustment: In the early 1980s, the "debt crisis" forced Ecuador, like many other economies, to undergo macroeconomic adjustment. To maintain debt service while limiting external-debt growth, it shifted in the mid-1980s from being a net importer to a net exporter of goods and non-factor services (see Table 1 and Figure 2). (Net exports returned to deficit in 1987, when an earthquake interrupted oil exports, and in 1998, when the exogenous shocks that set off the crisis reduced exports while anticipated exchange-rate depreciation encouraged imports.) Domestic saving remained essentially unchanged and capital formation declined, reducing real GDP growth (in turn limiting import demand). To set the incentives to increase net exports, policy-makers had to sustain a depreciated real-effective exchange rate. This turned out to require repeated nominal depreciation, leading to exchange-rate instability, and then to spontaneous dollarization and semi-dollarization (see Section 3).

Table 1. Gross fixed capital formation, gross domestic saving, and net imports of goods and nonfactor services (per cent of GDP)

\begin{tabular}{|l|r|r|}
\hline & Average: \\
\hline Percentage growth rate of real GDP & $1971-1982:$ & $\begin{array}{r}1983-1986, \\
1988-1997:^{*}\end{array}$ \\
\hline & 8.0 & 3.2 \\
\hline Per cent of GDP: & & \\
\hline Gross fixed capital formation & 21.9 & 18.6 \\
\hline Gross domestic saving** & 22.4 & 22.1 \\
\hline Net imports of goods and non-factor services & 1.8 & -2.6 \\
\hline & & \\
\hline Source: National accounts of Ecuador. & \\
\hline * 1987 is excluded because earthquake damage interrupted oil exports that year. \\
\hline ** Defined as total gross investment less net imports of goods and non-factor services. \\
\hline
\end{tabular}

\footnotetext{
${ }^{2}$ In the $1920 \mathrm{~s}$, for example, collapsing cacao export prices and a fungal attack on cacao trees caused a deep, lingering economic crisis with parallels to the present one.
} 
The external debt had begun accumulating in the 1970s. The start of large-scale oil exports generated a growth surge, and Ecuador's private sector took on external debt rapidly. Meanwhile, the military, who had taken power in 1972, applied the oil earnings to subsidize electric power and domestically-sold oil products, reduce non-oil taxes, and increase public employment. In the mid-1970s, however, when oil-export prices and revenues dipped, the Government itself chose to borrow abroad to finance widening public and current-account deficits rather than raise taxes or cut spending. Public and publicly-guaranteed external debt reached US\$3.3b at the end of 1980 (28 per cent of GDP), compared with US\$328m (20 per cent of GDP) at the end of 1971.

Figure 2. Ecuador: Gross fixed capital formation, gross domestic saving, and net imports of goods and nonfactor services (per cent of GDP), 1971-2000

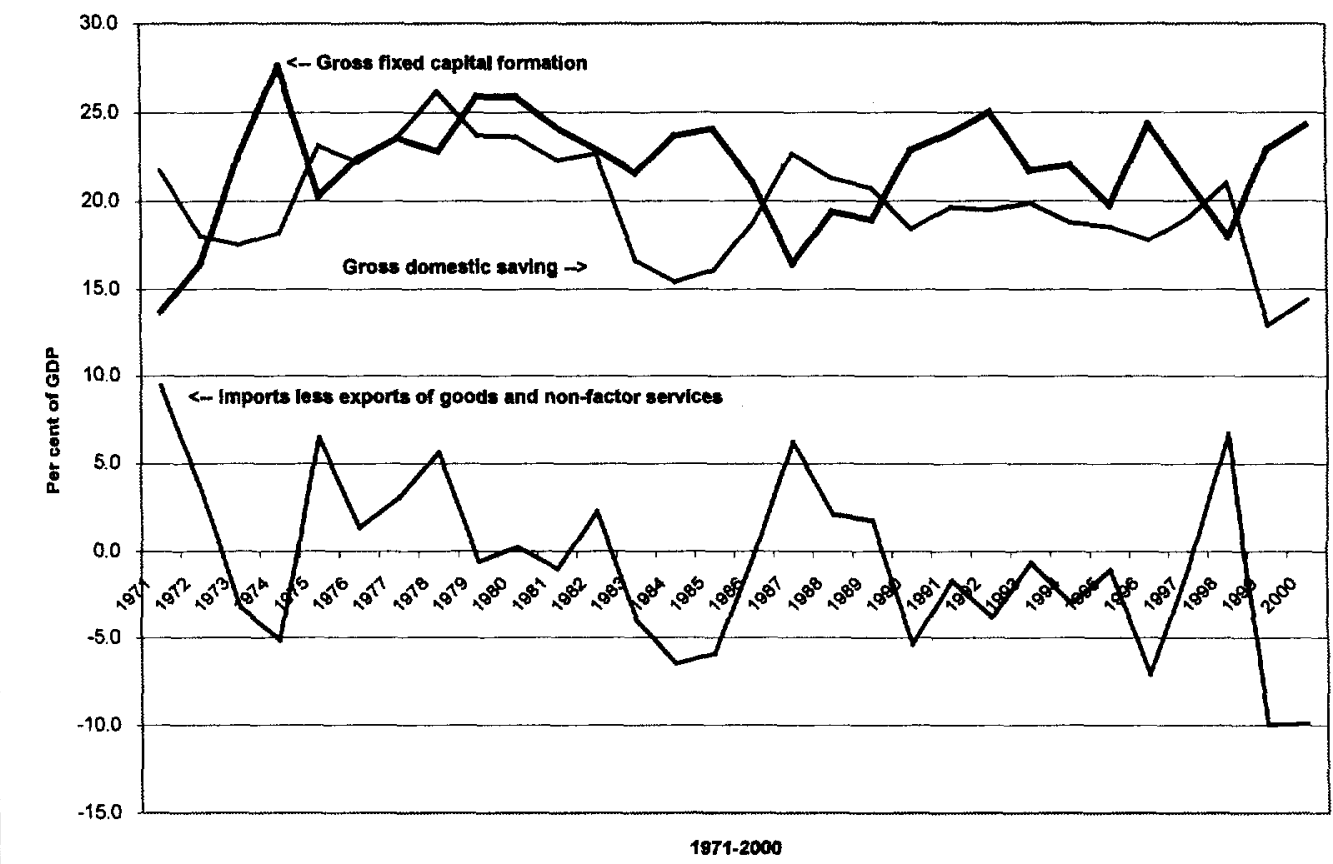

Data source: National accounts of Ecuador.

In the early 1980 s, surging interest rates on floating-rate commercial-bank debt and declining commodity-export prices thrust Ecuador into crisis. After the military gave way to constitutional government in 1979 , the authorities of various administrations struggled to set policies that would simultaneously meet external payments commitments, control public finances, and allow growth to resume. In May 1982, to stem the currentaccount deterioration, the authorities devalued the sucre, which had been pegged at 25 per dollar for nearly twelve years, by 25 per cent against the U.S. dollar (see Figure 3). This first "policy package" of adjustment to the debt crisis also included increases in banking-system interest rates (then subject to ceilings) and in public-sector goods and services prices. At the end of 1983, Ecuador's public and publicly guaranteed external debt totaled US\$5.5b (43 per cent of GDP). 
The 1982 devaluation and prospects of further devaluation affected private-sector external borrowers (mostly banks), who persuaded the authorities to provide relief. In 1983 , in the context of an IMF program, the Central Bank assumed about US\$1.5b in private external debt (about 11 per cent of 1982 GDP) in exchange for sucre-denominated debt. With subsequent devaluations, this "sucretización" policy amounted to a substantial (and highly unpopular) transfer to private debtors (see Bayas and Somensatto 1994). ${ }^{3}$ In 1992 the Central Bank transferred the debt remaining from the sucretización transactions, amounting then to about 8 per cent of GDP, to the Treasury.

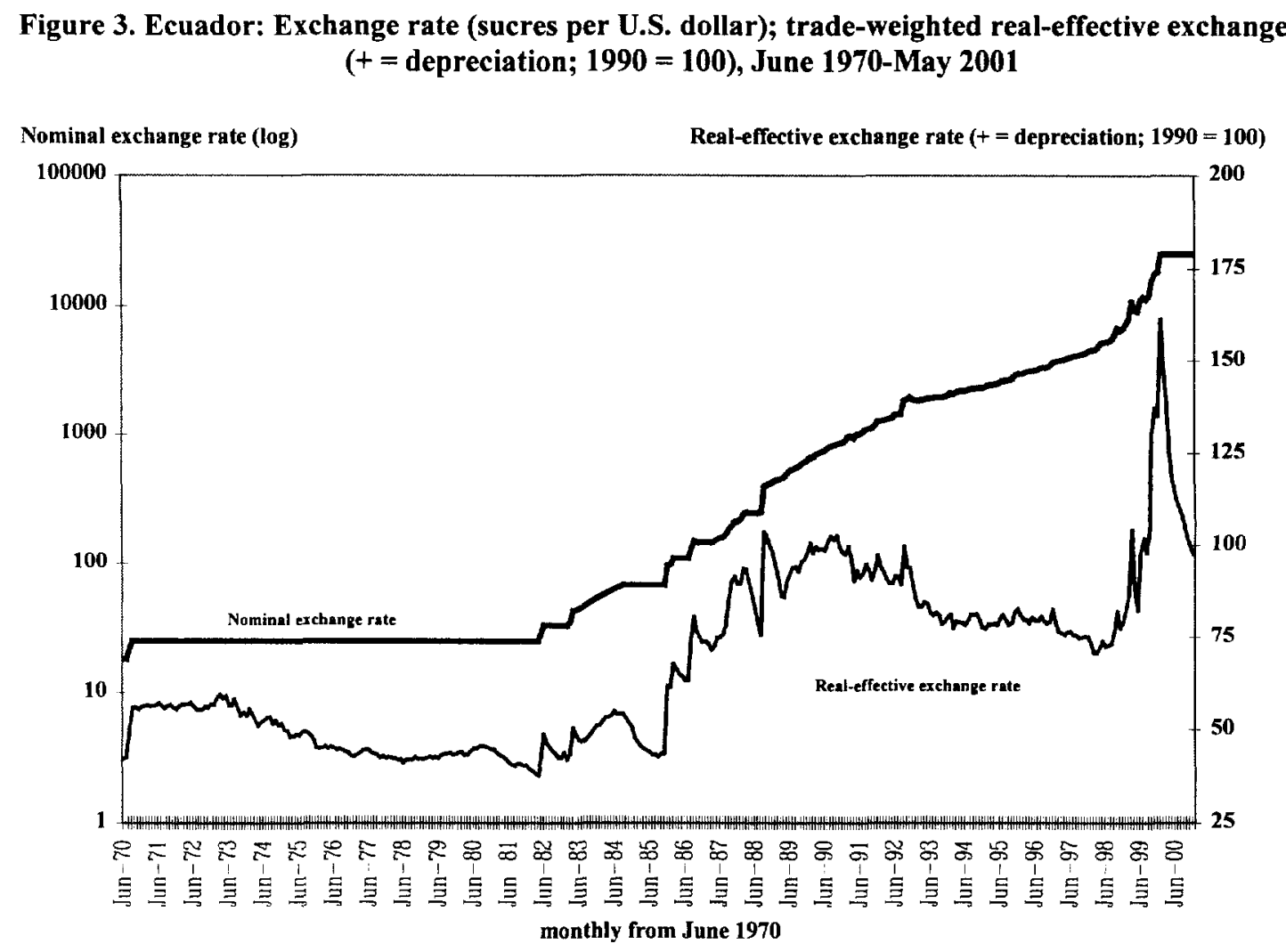

Data source: International Monetary Fund.

Consumer prices rose 24 and 53 per cent over 1982 and 1983, diluting the devaluation's incentive effects. In March 1983 the authorities devalued again, then began a policy of mini-devaluations to stay ahead of inflation. In 1986 a liberalizing Government instituted a floating exchange rate for private imports, at about the same time it liberalized commercial-bank interest rates. Oil-export prices declined sharply that year, however, and in January 1987 the Government interrupted debt service to foreign

\footnotetext{
${ }^{3}$ Even so, sucretización proved insufficient to resolve the private debt problem. By 1986, a large proportion of the private sector's sucre obligations to the Central Bank had become non-performing. That year, the Government authorized commercial banks to use external debt valued at par to service obligations to the Central Bank arising from the "sucretized" debt -- a further transfer from the public to the private sector, since this debt was purchased at substantial discounts.
} 
commercial banks. In March 1987 earthquake damage to the pipeline stopped oil exports for five months. International reserves diminished, and the sucre came under speculative attack. In mid-1987 the authorities retreated to mini-devaluations.

Even after oil exports resumed, the authorities failed to resume debt-service payments, and arrears to foreign commercial banks accumulated for seven years. Meanwhile, successive administrations struggled to set sustainable macroeconomic policy. In mid-1988, a newly elected Government enacted a new policy package, including another large devaluation and a new exchange-auction system for private importers. Inflation persisted at around 50 per cent from 1989 through 1991 and surged to 60 per cent in 1992, largely because the public deficit remained high. Low oil-export prices, at least until the Gulf War, were part of the problem. Although this Government made some progress on tax reform and financial-sector and trade adjustment, like many other Ecuadorian governments, the narrow scope for discretionary expenditure programming made fiscal control difficult.

In mid-1992 a newly elected Government liberalized and unified the exchange market, as part of a policy package intended to reverse an election-year surge in the public deficit. The following year, with inflation still running high and spontaneous dollarization already advancing (see Section 3), the Central Bank began a policy of allowing the exchange rate to float within a crawling-peg band. Ecuador received substantial financial inflows during 1993 and 1994 (see Jaramillo 1994), partly because the new exchange-rate policy reduced uncertainty. Many developing economies experienced substantial capital inflows at this time, as potential high returns and improving information brought "emerging markets" into vogue. Ecuador's inflows, however, went mainly into bank deposits, not to its underdeveloped equity markets. They came largely from Ecuadorian nationals, repatriating flight capital to take advantage of high sucre deposit rates. The inflows themselves reinforced exchange-rate stability, but the high sucre deposit rates made for a persisting problem: because they were continually capitalized into deposit stocks, the (broad) money supply tended to grow at high rates, helping to maintain "inertial" inflation. Nevertheless, the pre-announced crawling-peg exchange-rate band worked well enough, until the massive exogenous shocks of early 1998 forced devaluation outside the band. (Figure 4 shows the monthly evolution of the exchange rate and the band from January 1996 through March 1999, the month after the policy gave way to a float.)

The years 1993 and 1994 were relatively hopeful. The public deficit narrowed to about zero, real GDP grew 2 and 4.4 per cent, and inflation eased to 31 and 26 per cent. The Government began carrying out long-overdue structural reform, including a significant reform of public budget management; initial steps toward privatizing electric power and telecommunications, public-sector staff reductions, and improvements in tax administration. The Central Bank underwent a significant modernizing reform, under which its fiscal activities passed to the Finance Ministry. Approval of a new General Law of Financial Institutions in 1994 left the banking system as liberalized as any in the hemisphere, with banks allowed to operate in dollars and even to do business with Ecuadorian residents through off-shore branches. The arrears accumulation to 
commercial banks concluded in mid-1994, when, with IMF, World Bank and InterAmerican Development Bank (IDB) support, the authorities secured a debt-and-debtservice reduction (DDSR) deal, leaving Ecuador owing about US\$6b (36 per cent of GDP) in collateralized Brady bonds. The World Bank and IDB approved adjustment loans at the same time conditioned on substantial structural-reform efforts.

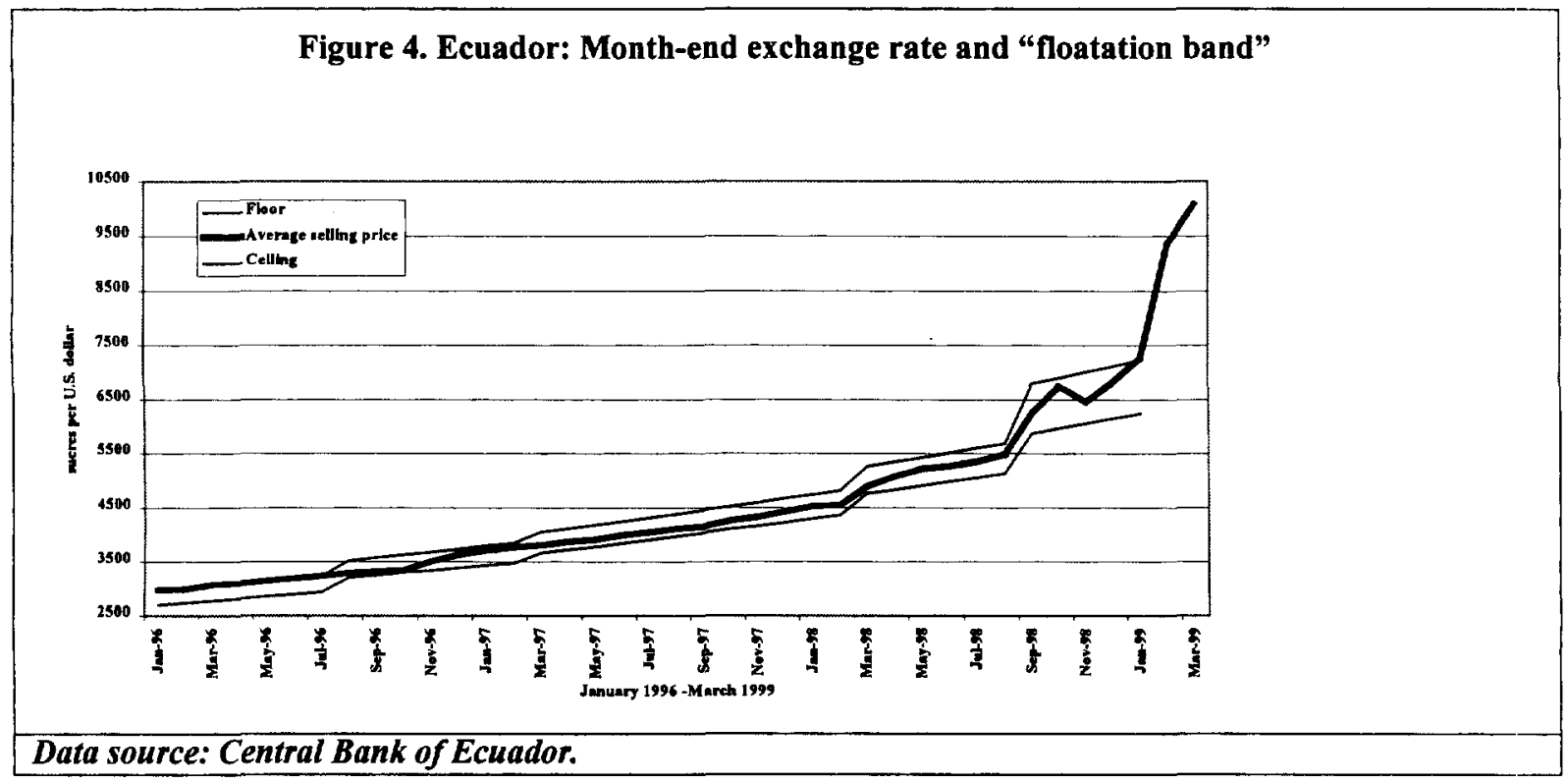

In 1995, however, economic prospects reversed. In January Ecuador fought a brief but costly border war with Perú. Drought later in the year affected real output. In October a large bank failed (it was taken over by the Central Bank). The same month, allegations of misuse of public funds forced the resignation of the Vice President, who had been coordinating economic policy. The two preceding years' capital inflows reversed, pressuring domestic interest rates up and slowing the economy. Ecuador also relapsed into political instability. The mid-1996 elections brought a "populist" government to office, but in February 1997 the Congress removed it because pervasive corruption and the President's unusual personal style had alarmed public opinion. It then installed an eighteen-month "Interim" Government, during which a constitutional assembly took place and new elections were organized for mid-1998. This Interim Government had an inadequate political mandate to deal with what would turn out to be the pre-dollarization crisis (see Section 4), as oil-export prices fell and El Niño rains commenced in late 1997.

Despite the years of macroeconomic adjustment, the public-sector debt stock remained high (see Figure 1). At the end of 1998 public and publicly guaranteed external debt outstanding totaled just over US\$13b, about two thirds of 1998 GDP, the heaviest burden by a wide margin among Latin America's ten largest economies. By the end of 1999, plunging real GDP and massive exchange-rate depreciation lifted the public debt- 
GDP ratio over 90 per cent. ${ }^{4}$ In addition, since the mid-1990s the public sector has accumulated substantial domestic debt. Domestic Treasury debt in bonds and bills rose from 1.2 per cent of GDP at the end of 1993 to 7.1 per cent at the end of 1998, 88 per cent of which was dollar-denominated. This ratio rose above 15 per cent at the end of 1999 , again, mainly on account of the sharp decline in the dollar value of GDP resulting from recession and exchange-rate depreciation. Notwithstanding the heavy borrowing, the public sector has incurred payments arrears to contractors and even to staff (schoolteachers endured several months of arrears during the first part of 1999). (In November 1999 the authorities unilaterally termed out almost all of the dollardenominated domestic debt for seven years, with two years' grace, at LIBOR plus two per cent interest.) Moreover, from December 1998 through 1999 the Treasury issued an additional US $\$ 1.6 \mathrm{~b}$ in dollar-denominated bonds in connection with the banking crisis (see Section 4).

(c) Lagging structural adjustment: Along with the economy's exposure to contingencies and its macroeconomic adjustment, the incompleteness and unevenness of structural reform have figured among the reasons for the economy's poor performance over the past two decades. They also help explain the economy's vulnerability to the 1998 shocks.

Ecuador went into the crisis in 1998 with a lengthy unfinished structuraladjustment agenda. In the public sector, changes still necessary included (i) oil-revenue stabilization mechanisms; (ii) reform of tax policy and tax and customs administration; (iii) reduction and targeting of public subsidies; (iv) reduction and improved management of public-sector staff; (v) measures to improve the efficiency and quality of expenditure on education, health and social welfare; (vi) modernization of systems for budget planning and execution; (vii) modernization of public capital formation and maintenance; (viii) completion of privatization and regulatory entities in the telecommunications, electric power, and hydrocarbons sectors; (ix) modernization of the social-security system; and (x) implementation of viable government decentralization. In the financial sector, the underlying problem was that although the system had been fully liberalized prudential supervision remained deficient, leaving wide scope for financial institutions to engage in risky practices. Finally, additional structural-adjustment agendas remained in the "flexibilization" of formal labor markets and for trade policy.

Ecuador's fiscal volatility is in many ways the legacy of government decisions taken in the 1970s. Public revenue depends excessively on volatile oil earnings (see Figure 5). In the four years 1996-1999, public oil-export earnings were respectively 4.9, $3.2,1.3$, and 5.1 per cent of GDP. Earnings from domestic oil-product sales have also been unsteady, because their prices have been subject to political pressures. Initiatives to increase tax revenue tend to run into political opposition, seeming unnecessary when oil earnings are high but too contractionary when low oil earnings reduce incomes. No less important, many people feel that too little of their taxes go to vital infrastructure and social services and too much to bureaucracy, corruption, debt service, and private-sector

\footnotetext{
"The August 2000 "debt exchange," through which Ecuador purchased US\$6.5b in Brady and Euro bonds with US $\$ 3.9 \mathrm{~b}$ in new bonds, provided some relief, but the external-debt burden remains heavy, especially since the IMF and multilateral agencies promised loans exceeding US\$2b over 2000, 2001 and 2002.
} 
bailouts (such as the unpopular sucretización program and the more recent transfers to failing banks).

In recent years, Ecuador's Congress has rejected or severely weakened several integral tax-reform initiatives. Until 2000 , the VAT rate was just 10 per cent, and the $12-$ per-cent rate that took effect in 2000 is below the rates in comparable Latin American economies. In January 1999, the Government hastily replaced the poorly performing personal and corporate income tax with a one-per-cent tax on financial transactions, including checks. The Government badly needed to increase revenue, and this levy was the only revenue measure the Congress would approve. Its yield was high during 1999 and 2000 (about 3 per cent of GDP), but was distorting, damaging bank performance at a particularly bad moment. In April 1999 the Congress partially reversed policy and approved legislation restoring the income tax, and in November it reduced the transactions tax to a negligible level (retaining it because the information it provides assists tax administration generally). Tax and customs administration have been especially problematic, although there have been some promising modernizing reforms in recent years. (Kopits et al 1999 provides a diagnosis of the taxation system.)

Figure 5. Ecuador: Per-capita non-financial public-sector revenue (in 1999 U.S. dollars and prices)

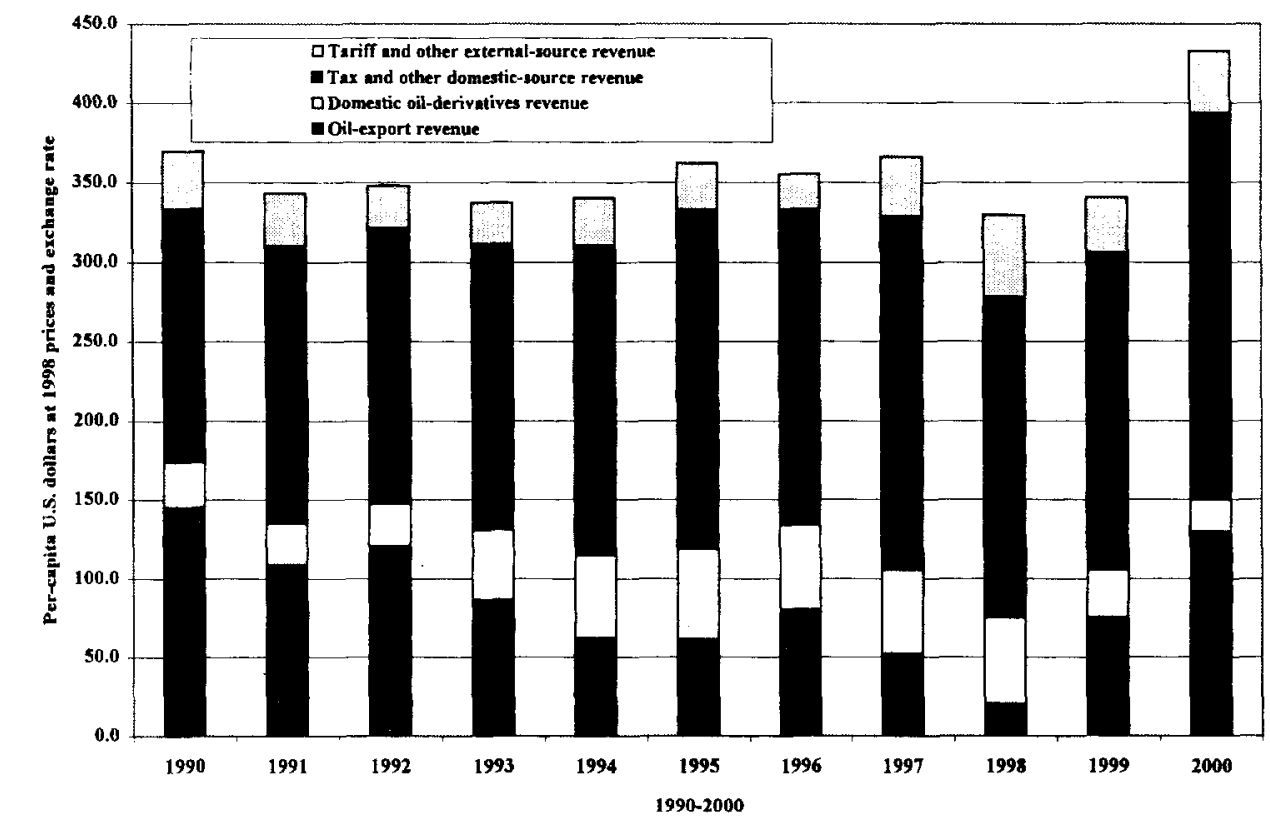

Data source: Central Bank of Ecuador.

On the expenditure side, the non-financial public sector's 1998 accrued interest bill was 5.1 per cent of GDP (3.8 percentage points of which were external). (In 1999, estimated accrued interest reached 10.1 per cent of GDP, of which external interest accounted for 6.4 percentage points -- again, largely because recession and exchange-rate depreciation reduced the GDP figure in this ratio's denominator). The non-financial public-sector staff totals nearly 400,000 and the payroll has been around 7 and 8 per cent 
of GDP. Under existing rules most staff are tenured. About 90 per cent of public workers work in education, health, police and defense. (See Figure 6, which shows the main components of Central Government expenditure -- (a) education, health, and social welfare, (b) transport and communications infrastructure; and (c) other non-interest expenditure; and (d) interest on the public debt). An unusually large proportion of overall revenue is "earmarked," further limiting policy-makers' discretion.

Figure 6. Ecuador: Per-capita Central Government expenditure (in 1999 U.S. dollars and prices)

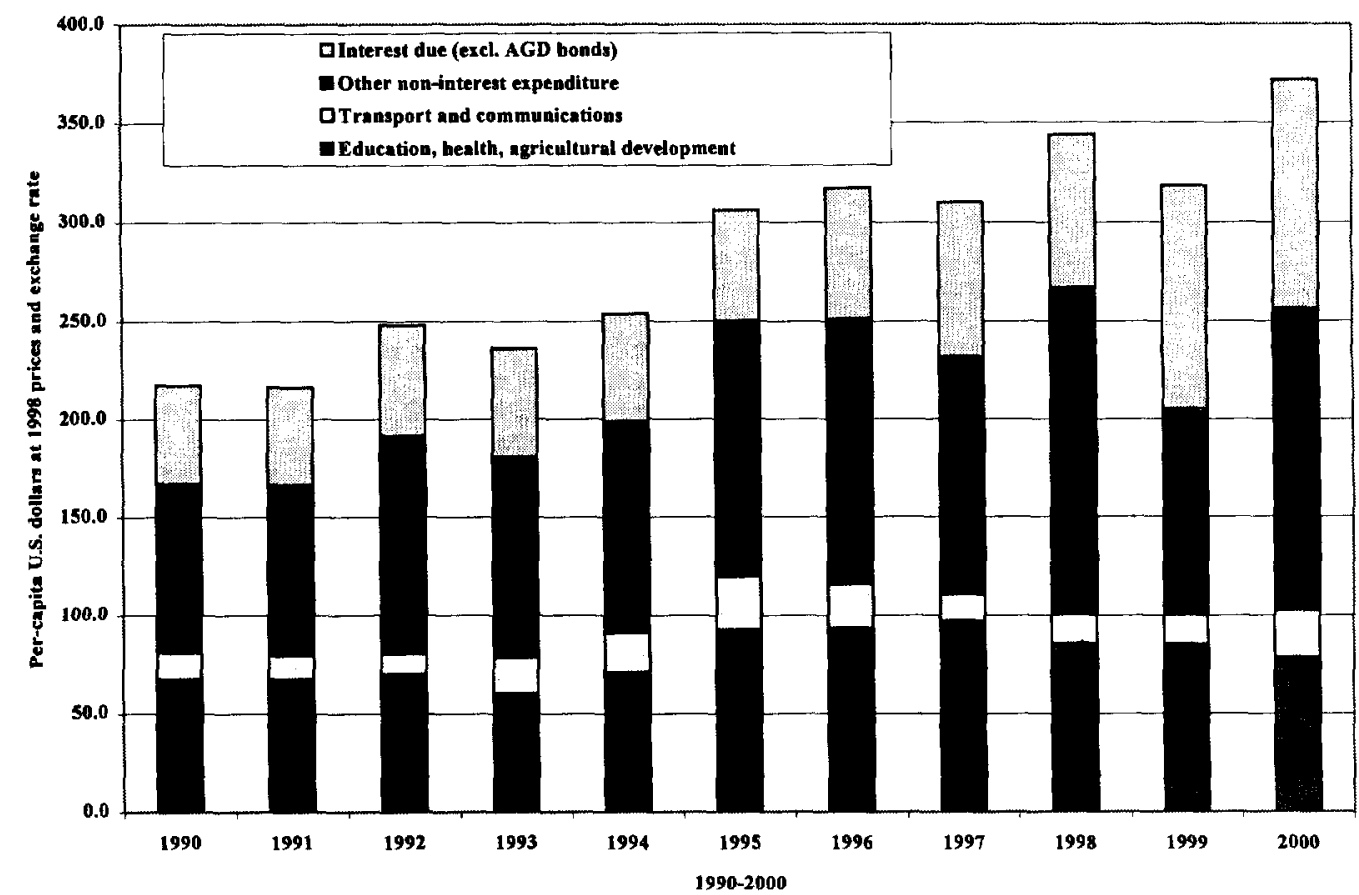

Data source: Central Bank of Ecuador.

Outmoded budget formulation and execution procedures have affected expenditure management. Modernization has proceeded slowly: the 1992 Public Budgets Law set a legal basis, but (as in neighboring economies) technical difficulties have delayed implementation of computerized systems. Planning, budgeting and execution of public capital formation have been especially problematic. Budget pressures have made public-sector capital projects vulnerable to across-the-board (rather than prioritized) budget cuts. Monitoring systems are only now being modernized.

One consequence of the 1998 shocks was a destabilizing "flip" in the fiscal accounts' exchange-rate sensitivity. Over most of the 1990s, with import flows and oilexport prices at "normal" levels, exchange-rate depreciation tended to reduce the fiscal deficit, even with the high level of debt service. In 1998, however, after oil-export prices 
declined and the stocks of dollar domestic and external debt issues increased, exchangerate depreciation tended to widen the deficit. ${ }^{5}$

Figure 7 shows the high primary (non-interest) surplus and the interest bill. A primary deficit appeared only in the crisis year 1998, when oil revenue was unusually low. This surplus is undoubtedly a standing drag on economic growth, through the multiplier effects of forgone public expenditure, inadequate social-services expenditure, and the consequences for productive capacity of forgone public-sector capital formation. Like the net-export surplus on the external accounts, however, the primary fiscal surplus helps meet the high debt service.

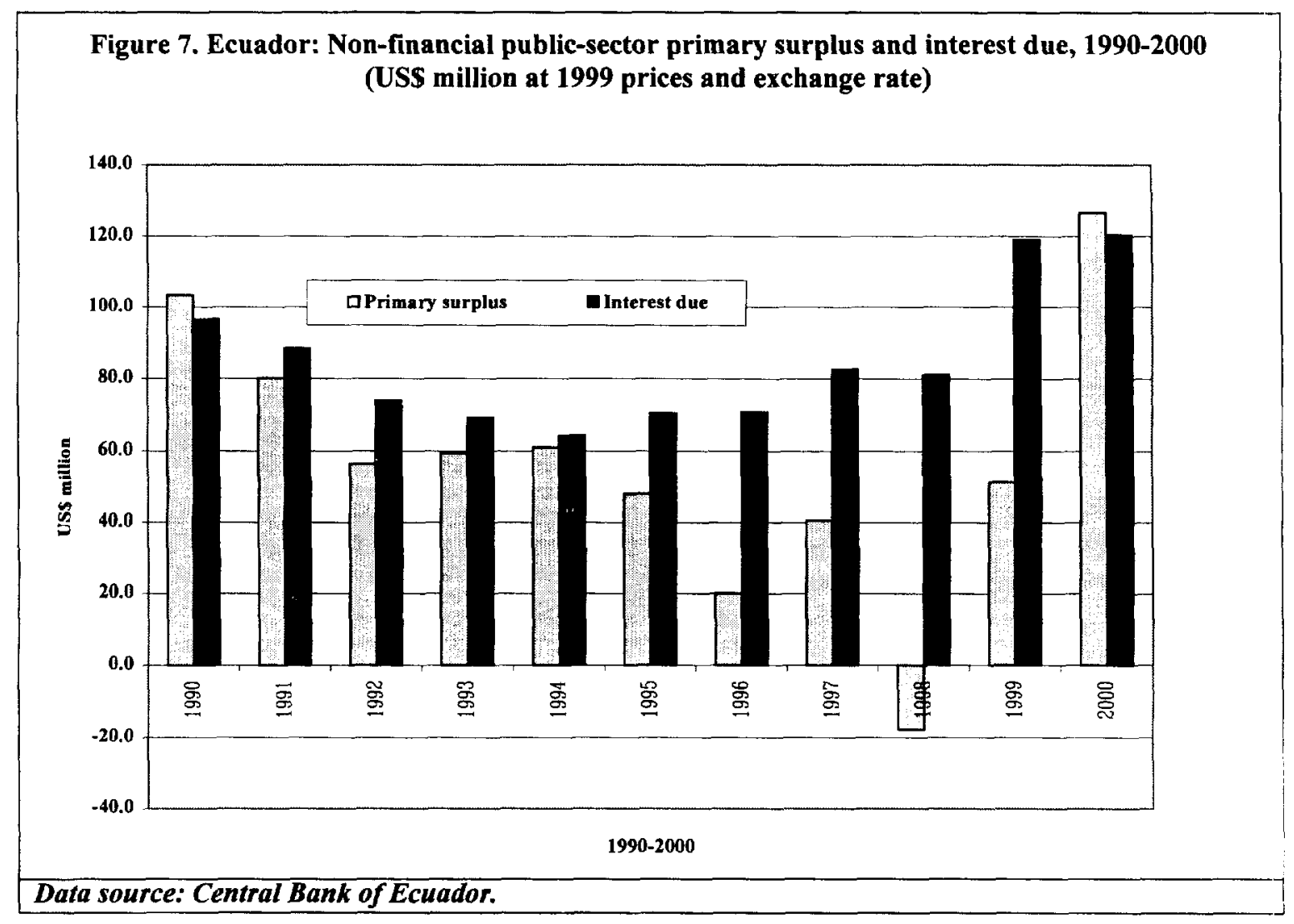

Three other long-standing public-sector structural issues - privatization, social security and decentralization -- go beyond the fiscal system per se. Progress on privatization has been slow, not only because of political opposition, but also because reorganization of the telecommunications, electricity and hydrocarbons enterprises into privatizable entities has proven technically difficult, and also because Ecuador's

\footnotetext{
${ }^{5}$ This can be seen by estimating the non-financial public-sector accounts' "dollarized base" - roughly, the sum of crude-oil export revenue and tariff revenue, less the interest bill (including interest on domestic Treasury debt, which was largely dollarized by the end of the 1990s). Over most of the 1990 s this figure was positive, ranging between US\$606m in 1992 and US\$83m in 1997. In 1998, however, this measure dipped below zero, to US $\$ 114 \mathrm{~m}$ in 1998 . In 1999 , rising oil revenues lifted this figure back above zero.
} 
uncertainties have discouraged investor interest. The social-security system has become increasingly unviable: Ecuador has long needed to carry out a reform like those of Chile, Uruguay and Bolivia, both to restore the system's longer-term financial viability and to open a private-sector role in pensions. Political opposition to reform has proven difficult to overcome, however. Finally, there is the complex issue of decentralization. Ecuador is now a centralized, unitary state. Decentralization advocates argue that reallocation of political and administrative decision-making to more appropriate governmental levels ("subsidiarity") would relieve interregional rivalry and make government more effective at all levels. Participants in these debates are aware, however, that decentralization has many pitfalls, and proponents have divergent views on precisely how it should be done. The fiscal aspects are among the thorniest. Ecuador's sub-national governments are financially pressed, because existing law and outdated property values constrain their revenue-generation capacity.

Beyond the public sector, the financial system has been a clear example of the dangers of uneven structural reform. Over the 1980s and early 1990s, the financial system gradually moved from tight regulation to thorough liberalization. In addition, the Central Bank underwent thorough reform, changing from a regulating entity with subsidized credit operations into a modern institution restricted to pure central-banking operations. A 1992 reform prohibited the Central Bank from lending directly to the government, ${ }^{6}$ and a 1998 constitutional change made it legally independent. The problem was that development of prudential regulation lagged. The Banking Superintendency not only remained technically weak; its officials were vulnerable to legal and other kinds of intimidation by bank officials and owners. The banking system therefore maintained many long-standing risky practices, such as connected lending and portfolio concentration, and developed some new ones, including abusive use of off-shore operations, aggressive interest-rate competition, and dollarization. Banks and regulators alike were poorly prepared for the 1998 shocks. Regulators could not determine rapidly enough how serious banks' problems were, and in any case their intervention powers were inadequate. As late as 1998, there was no deposit-insurance agency, and the authorities had no intervention powers short of the drastic step of liquidation.

Structural reform has lagged in other sectors. Going into dollarization, labor law was still relatively inflexible, and there was an anachronistic, centralized system of formal-sector wage determination. Although Ecuador carried out substantial trade reform and domestic price liberalization in the late 1980 s and early $1990 \mathrm{~s}$, tariffs still have an anachronistic structure favoring imported inputs over final goods.

Structural reform has lagged for many reasons. Ecuador's presidential powers are limited by comparison with other countries, and public administration - such as tax administration, banking supervision, disaster management, and so on -- has tended to be limited in power, resources and capacities. This is partly because the historic rivalry between the "Costa" region, centered on the port city of Guayaquil, and the "Sierra" region, centered on the capital, Quito, has led to limitations on central-government

\footnotetext{
${ }^{6}$ This reform was less restrictive than it semed. By easing liquidity conditions, the Central Bank could still make it easier for commercial banks to take on Treasury obligations.
} 
power. Public officials have often been subject to impeachment and judicial action on political grounds. Political parties are fragmented, representing multi-dimensional regional, ideological, and ethnic interests (one political party claims to speak for indigenous people). At this writing, the (unicameral) Congress has ten parties, none close to a majority. The executive has often had to seek legislation for what would elsewhere be done administratively. Securing congressional approval requires it to piece together coalitions, making compromises and deals to win support. On some occasions this has simply proved impossible. Congress has often rejected vital legislation, or made changes that either weakened it or created new difficulties, sometimes forcing presidents to veto legislation they had themselves proposed.

\section{3. "Semi-dollarization"}

Over the latter part of the 1980s and then the 1990s, Ecuador's economy became semidollarized. Section 4 argues that this made the 1998 shocks more destabilizing than they would otherwise have been. This section discusses the spontaneous dollarization process.

Spontaneous dollarization took place because Ecuadorians sought a stable unit of account for wealth and contractual relationships once the purchasing power of its own currency had become unstable. Two additional causes of dollarization were (i) "globalization," which meant that Ecuadorians engaged in an increasing number of dollar-denominated transactions with non-residents; and (ii) the increasing "density" of contractual relationships in the economy as it modernized, which deepened the need for a unit of account with stable purchasing power. The growing number of people who rented out housing, placed savings at interest, sold professional services, undertook commercial contractual relationships, and so on tended to insist on the dollar as the unit of account, to the extent they possessed the "market power" to do so. People on purchasing sides of contractual relationships presumably preferred to use depreciating local currency. To do so, however, they would have had to pay premia high enough to compensate not only for expected depreciation of the local currency against the dollar, but also for the associated uncertainty. Given a choice between high premia and dollar denomination, purchasers often settled for the latter (although they sometimes found ex post that they would have been better off in sucres with the high premia).

It stands to reason that dollarization has gone furthest in economies with long inflation histories, such as Argentina, Bolivia, Perú, and Ecuador. ${ }^{7}$ Experience suggests that government attempts to reverse spontaneous dollarization do more harm than good. In 1982 Bolivia's Government directed banks to convert dollar accounts to local currency. Subsequent withdrawals and consequent destabilization helped precipitate Bolivia's slide into hyperinflation. In 1986 Perú's Government, similarly, directed banks to convert dollar accounts to local currency, with similar results: conversion of dollar accounts discouraged depositors and produced withdrawal demand that had to be met

\footnotetext{
${ }^{7}$ One reason dollarization had not proceeded as fast and as far in Brazil as in other economies despite high inflation was its use of financial indexation, which afforded wealth holders some protection from inflationary uncertainty. Dollarization has advanced in Brazil since formal indexation ended in 1994.
} 
largely through liquidity creation. In both cases, while other aspects of economic policy contributed to hyperinflation, conversion of dollar accounts was a destabilizing trigger. No doubt mindful of this experience, Ecuador's authorities concluded it was best, or least bad, to allow dollarization to follow private preferences.

Table 2. Ecuador: Indicators of semi-dollarization

\begin{tabular}{|r|r|r|r|}
\hline Year & Year-end percentage in U.S. dollars of: \\
\hline & $\begin{array}{r}\text { Quasi- } \\
\text { money }\end{array}$ & Deposits & $\begin{array}{r}\text { Loan } \\
\text { portfolio }\end{array}$ \\
\hline 1989 & 9.7 & 14.7 & 1.9 \\
\hline 1990 & 7.4 & 13.3 & 1.5 \\
\hline 1991 & 7.5 & 14.5 & 3.0 \\
\hline 1992 & 10.8 & 20.0 & 6.8 \\
\hline 1993 & 12.6 & 16.9 & 13.4 \\
\hline 1994 & 15.7 & 15.6 & 20.3 \\
\hline 1995 & 24.3 & 19.2 & 28.3 \\
\hline 1996 & 28.0 & 22.3 & 32.6 \\
\hline 1997 & 36.9 & 23.6 & 45.1 \\
\hline 1998 & 43.9 & 36.9 & 60.4 \\
\hline 1999 & 47.4 & 53.7 & 66.5 \\
\hline Data source: Central Bank of Ecuador. \\
\hline
\end{tabular}

The dollar-denominated proportion of Ecuador's broad (on-shore) money supply (including quasi-money) rose from 3.9 per cent at the end of 1990 to 34.6 per cent at the end of 1998 (see Table 2 and Figure 8). This measure understates the extent of dollarization, for two reasons. First, dollar currency was increasingly used within Ecuador for transactions. Second, Ecuadorians made increasing use of off-shore deposits, which were not included in official money-supply figures. According to estimates prepared for July 1999 , overall banking-system deposits totaled US $\$ 6.4 \mathrm{~b}$. Onshore deposits totaled US $\$ 3.5 \mathrm{~b}$, while off-shore deposits totaled US $\$ 2.9 \mathrm{~b}$. Of the onshore deposits, US $\$ 1.7 \mathrm{~b}$ was in sucres, and all off-shore deposits were in dollars.

As the monetary and banking indicators in Table 2 show, dollarization progressed slowly at first, but became pervasive by the mid-1990s, especially after exchange-rate depreciation mechanically increased the sucre equivalent of dollar balances. (Again, these indicators cover only on-shore banks, and so under-report the extent of dollarization.) In December 1996, 24 per cent of all on-shore bank demand, savings and time deposits were in dollars rather than sucres; in December 1998, this percentage had risen to 41, and in March 2000 it stood at 63 (see Figure $9^{8}$ ). In December 1994, 33 per cent of all bank loans were in dollars; in December 1998, this percentage had risen to 60 , and in March 2000 it reached 91. Over this period, the commercial banks' overall deposit base declined about thirty per cent in dollar terms, with sucre deposits falling more than two thirds while dollar deposits grew.

\footnotetext{
${ }^{8}$ The shrinkage of the sucre deposit base measured in dollars resulted partly from the real-effective depreciation.
} 
Figure 8. Ecuador: Broad money supply (M2) and its currency composition (per cent of GDP)

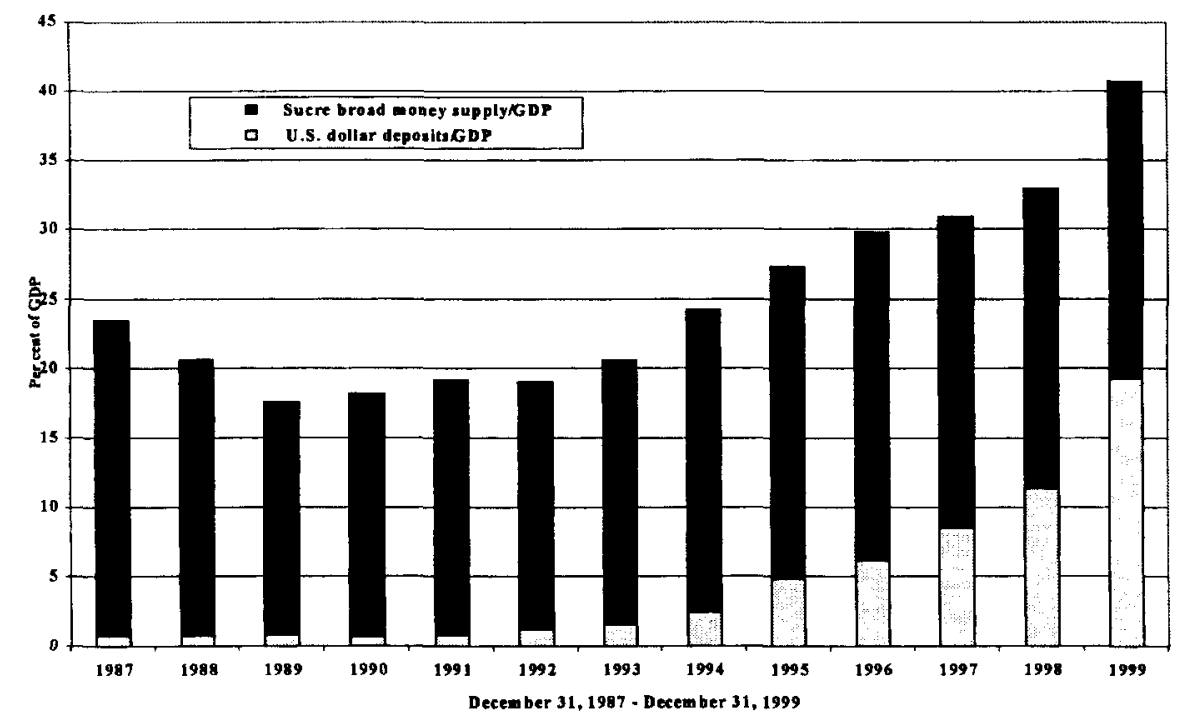

Data source: Central Bank of Ecuador.

Where the money supply is semi-dollarized, exchange-rate depreciation directly increases the local-currency value of its dollar part. The inflationary impact of exchangerate depreciation is therefore larger and probably more rapid than it would otherwise be. Since inflation following exchange-rate depreciation erodes some of the real-effective effect, more depreciation may be required, all other things being equal, to achieve any particular external-accounts objective. Moreover, once the price level and exchange rate begin rising, they affect expectations and uncertainty regarding future inflation and depreciation, and encourage further spontaneous dollarization.

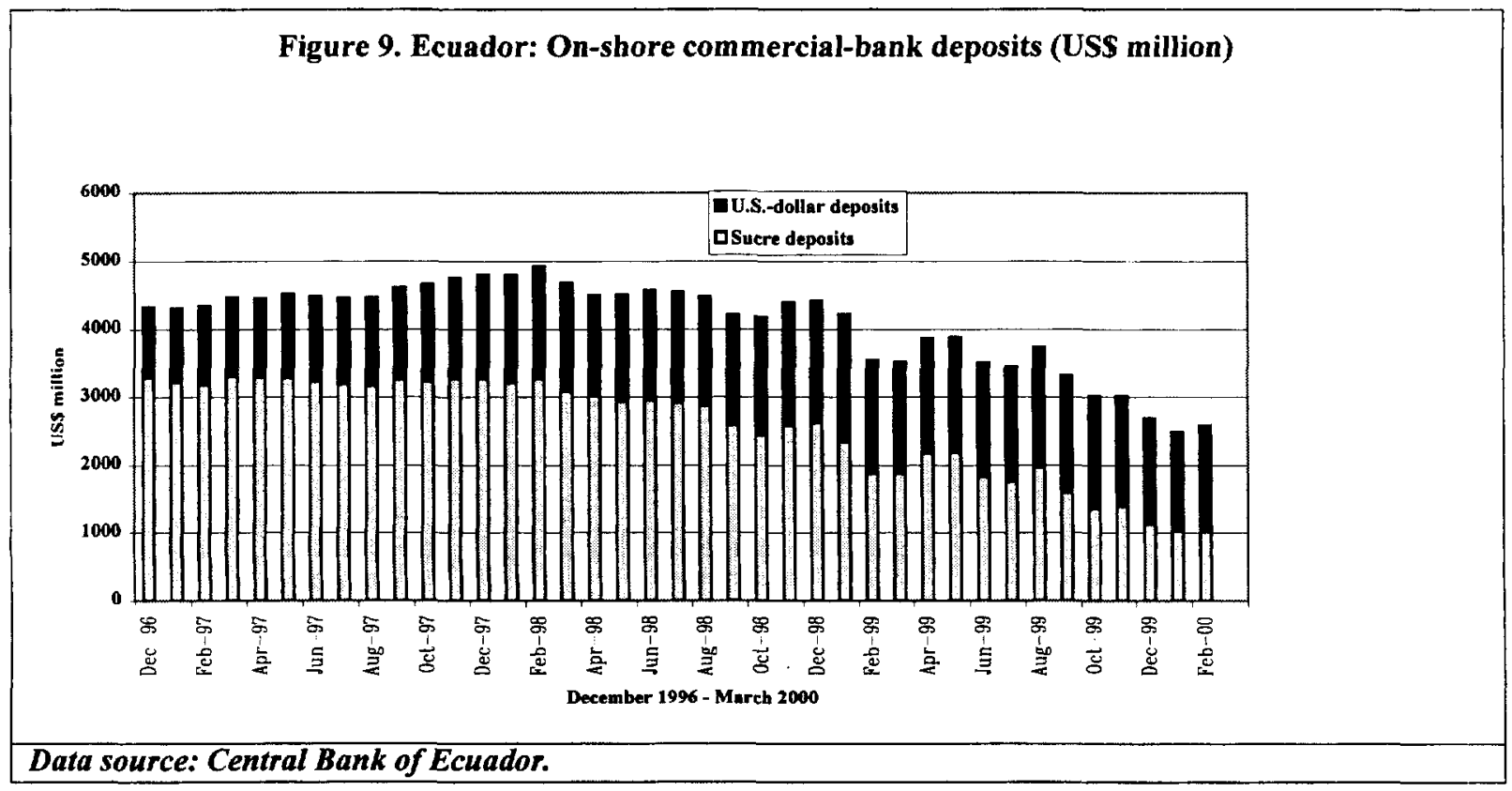


Evolving inflationary expectations and uncertainty and shifts in the money stocks denominated in the two units of account may then affect local-currency and dollar interest rates, in complex ways. In a semi-dollarized system, with some interest rates in dollars and some in the national currency unit, relative interest-rate movements become difficult for market participants and policy-makers alike to interpret. Even in an undollarized system, it is usually impossible to know to what extent rising interest rates reflect rising inflationary expectations and uncertainty rather than real scarcity of financial resources. In a semi-dollarized system, relative domestic-currency and dollar interest rates respond to and influence relative supplies of and demand for financial resources in the two units of account. For example, banks receiving a sudden influx of dollar deposits might reduce dollar lending rates and raise local-currency lending rates, to encourage dollar borrowing to meet asset-liability matching objectives. Policy-makers conceivably could respond to rising local-currency interest rates by easing monetary policy. This might produce expectations of higher inflation, however, and induce further surges in dollar deposits, hence further reductions in dollar interest rates and further increases in local-currency rates. Where the authorities attempt to support an exchange rate by propping up local-currency interest rates, the circumstances can become especially difficult to interpret. The role of interest rates is all the more complicated where deposit rates are at double-digit nominal levels, because capitalization of interest into deposit stocks implies that local-currency deposit stocks tend to grow at rates on the order of the interest rates.

In addition, the fact that the economy is operating in two units of account with an unstable exchange rate implies that at least some entities have unmatched positions. Exchange-rate depreciation poses significant risks not only to entities whose dollar obligations are inadequately matched with dollar earnings, but also to entities whose dollar assets are the unmatched entities' obligations. Ecuador's "pre-dollarization" crisis illustrates this point all too clearly (see Section 4).

\section{The "pre-dollarization" crisis}

In late 1997 and early 1998 Ecuador was struck by a combination of climatic and external shocks, including damaging El Niño rains; ${ }^{9}$ plunging crude-oil export prices (see Figure 10); and various effects of the East Asian, Russian and Brazilian financial crises. These last included recession in export markets, intensified competition in export markets from countries whose exchange rates had depreciated, and closure of private world financial markets as they reevaluated developing economies' risk. Because of the characteristics of the economy and political system as they had evolved since the mid1970 s, these shocks induced macroeconomic dynamics that policy-makers could not manage. This section describes this experience. The economic and political characteristics that mattered most included public-sector dependence on volatile oil

\footnotetext{
${ }^{9}$ Damage included destruction of 2,500 kms. of roads and 19 bridges, as well as a large amount of agricultural production (especially bananas). The monetary value of the damage has been estimated at US $\$ 2.6$ billion, about 13 per cent of 1998 GDP.
} 
earnings, the banking system's exposure to activities affected by the shocks; inadequate banking supervision, the massive public external debt; the political fragmentation of the Congress, weak public administration, and the political pressure to subsidize energy. Semi-dollarization was especially important: rapid exchange-rate depreciation overwhelmed the dual-currency banking system and its unmatched borrowers.

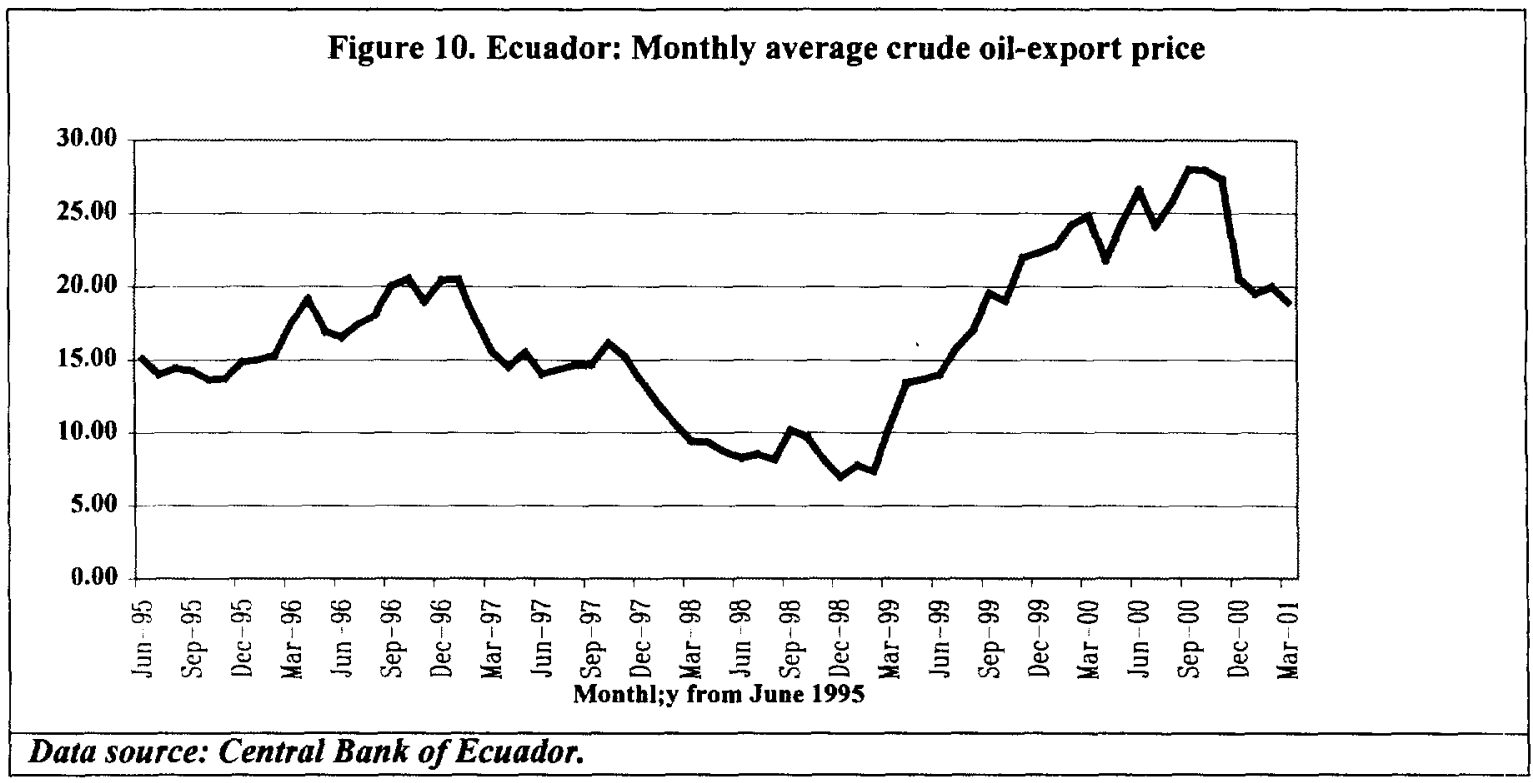

The shocks reduced oil and tax revenue, widening the fiscal deficit, and reduced exports, widening the current-account deficit. The mid-1998 presidential election made it politically harder to tighten fiscal policy to cope with the shocks. The 1998 non-financial public deficit reached 5.7 per cent of GDP (compared with 2.6 per cent in 1997). ${ }^{10}$ Because commercial banks had lent heavily to oil suppliers, coastal agriculture, and exporters, the shocks damaged their loan portfolios. Even so, in early 1998 the Central Bank took the view that it had to tighten credit and raise interest rates to defend the exchange rate and control inflation. Many foreign banks retracted trade-credit lines, a serious problem because many enterprises depended on these for working capital and because the banks were increasingly illiquid. In March 1998 a relatively small bank failed; in April some banks endured deposit runs of varying severity; and in August, a week after the newly-elected government took office, a larger bank failed. While oilexport earnings declined, importers increased their orders for inventory, anticipating that the authorities would be forced to devalue outside the pre-announced crawling-peg band. The Central Bank did so twice during 1988, in March and September. Even so, the 1998 current-account deficit soared to 11 per cent of GDP (compared with 3.6 per cent in 1997). It was financed to a large degree through international-reserve losses and private financial transfers.

\footnotetext{
${ }^{10}$ The recorded 1998 deficit would have been larger, but the Central Bank paid a dividend amounting to 0.6 per cent of GDP to the Treasury, which would be counted as financing under standard IMF methodology.
} 
In the latter part of the year, as the banking crisis deepened and deposit withdrawals intensified, the new authorities decided to seek legislative approval for a universal deposit guarantee. In December 1998 the Congress and Executive approved emergency legislation extending a virtually unlimited Treasury cash guarantee to all bank deposits and even to their trade-credit lines. This dramatically increased the stakes for the government, but could not resolve the banks' credibility problem. The guarantee was credible as such only for small institutions. If larger banks failed, fiscal constraints implied that the authorities would either have to keep them open or somehow honor the guarantee less than fully. The guarantee may have helped slow the pace of deposit withdrawals for a time, but its inherent credibility problem ultimately undermined its objective. (This legislation also included the one-per-cent transactions tax discussed in Section 2 above.)

The same legislation also established Ecuador's first Deposit Guarantee Agency (AGD), and defined the modalities through which it could intervene in troubled banks without liquidating them. On December 1, 1998, the day it began operating, the AGD took over the nation's largest bank. In a pattern to be followed for larger banks that failed during 1999, the authorities kept the bank open. To do so, they recapitalized the bank with newly issued ten-year Treasury bonds yielding 12-per-cent annual interest. The bank used the bonds as collateral for Central Bank liquidity loans to meet withdrawal demand. In January 1999 several smaller banks failed, and these were eventually liquidated, with the deposits paid out (after several months' delay) by the AGD.

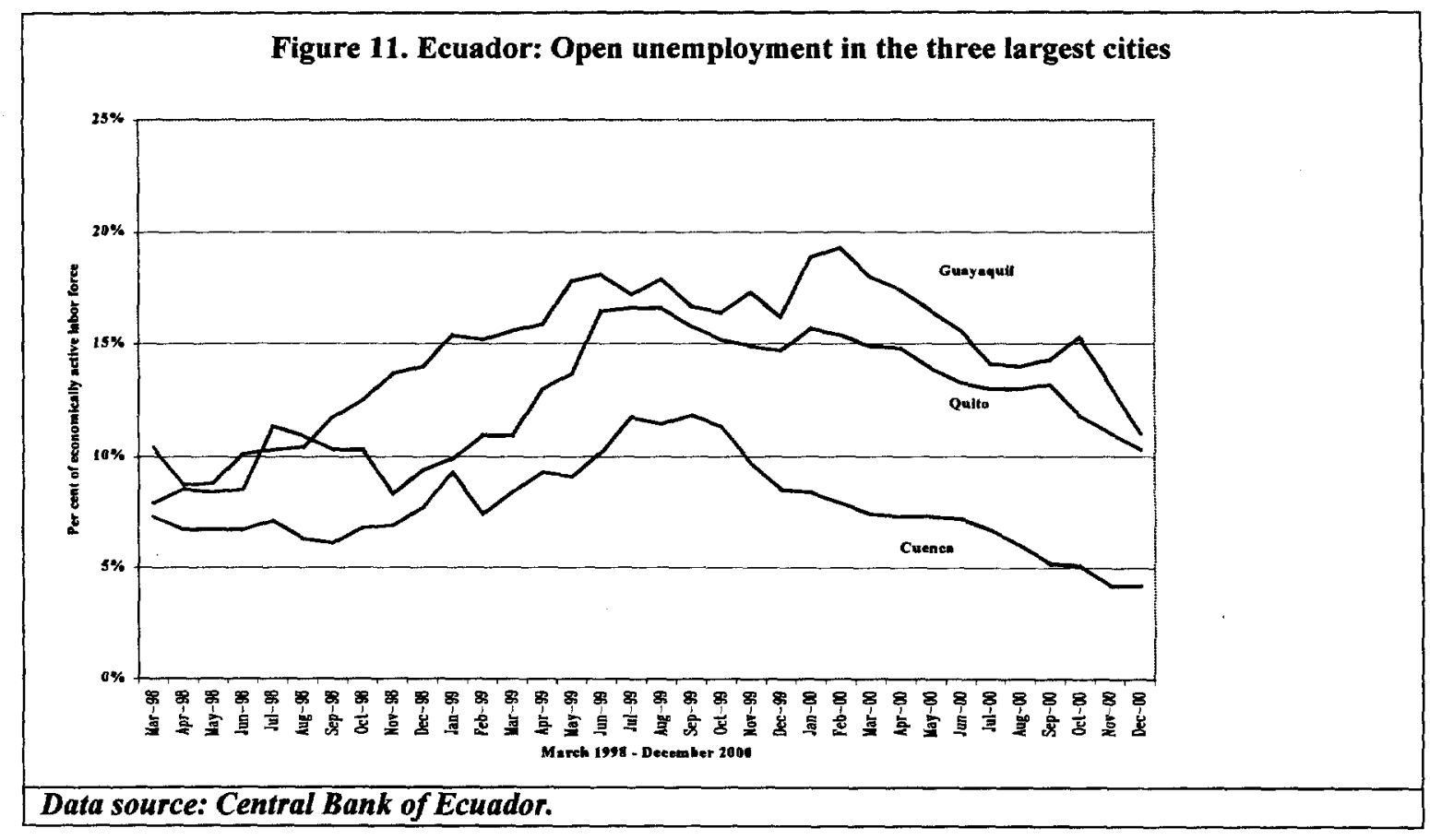


In February 1999, the Central Bank floated the exchange rate to limit foreignexchange reserve loss, ending the crawling-peg band system. ${ }^{11}$ The sucre lost 30 per cent of its U.S.-dollar value over the next four weeks, inducing incipient hyperinflation: consumer prices were 13.5 per cent higher in March than in February. Several banks, notably a large Guayaquil-based bank that had engaged aggressively in "high interestrate" operations, were in danger. In mid-March, to control inflation and to prevent further bank failure, the Government first declared a bank holiday, then announced a oneyear freeze on most deposits. At the same time, it promised to hire international auditing firms to determine the banks' true capital positions. Although the freeze temporarily reversed the exchange-rate depreciation and slowed the inflation, it inevitably disrupted real economic activity. Banking-system credit operations, already shrinking, virtually ceased with the freeze. This, together with curtailment of access to transactions balances, helps explain why real GDP declined 7.3 per cent in 1999 and urban unemployment roughly doubled between mid-1998 and December 1999 (see Figure 11).

On July 30, on the basis of the auditing firms' results, the Banking Superintendent stated in a televised speech that of the 32 banks examined (including three already closed), nineteen were sound, six more would be closed and four relatively large banks would undergo enhanced monitoring, recapitalization and restructuring under the Deposit Guarantee Agency. Three of these four banks failed within two months, however. The authorities kept these three banks open, merging them with other banks the Agency already owned. In all, by December 1999 banks representing more than 60 per cent of total commercial-bank assets were in public hands.

Figure 12. Ecuador: On-shore commercial-bank loans performing normally and in arrears

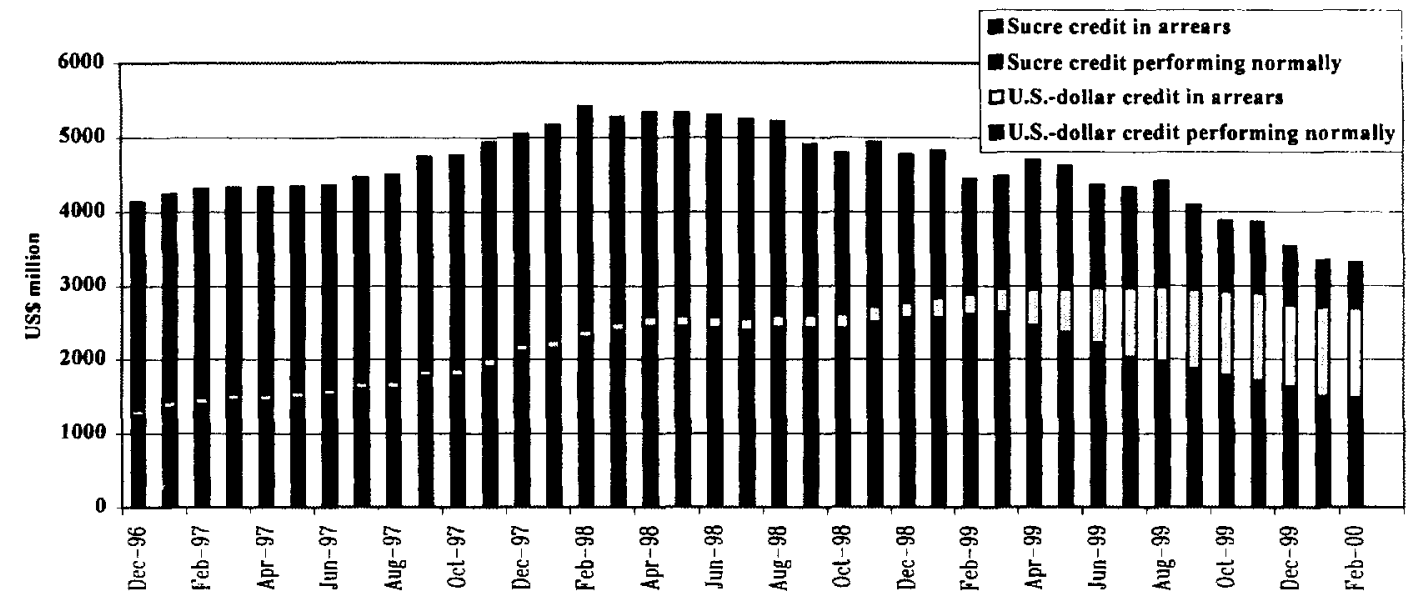

Data source: Central Bank of Ecuador.

${ }^{11}$ Because the 1999 Budget incorporated an exchange-rate assumption that would no longer have been plausible once the float began, the Government delayed the float, at a substantial cost in reserve loss, until the Congress could approve the Budget, in mid-February. Brazil's January 1999 devaluation had intensified the pressure on Ecuador.'s exchange rate. 
Figure 12 shows the extent of the damage to banks' loan portfolios. After December 1998, the proportion of dollar-denominated loans classified as non-performing rose sharply, in contrast to sucre loans - partly because many dollar borrowers were unmatched, but also because exchange-rate depreciation caused the dollar loan stock to grow relative to the sucre stock. ${ }^{12}$

The freeze term was to have been one year for checking and savings deposits and one year from the original maturity date for time deposits. Within weeks, however, hoping to ease the damage, the authorities began unfreezing checking deposits. Over the remainder of 1999, they accelerated the unfreezing of checking and savings deposits. They also allowed conversion of time deposits into marketable "Reprogrammable Certificates of Deposit," which could be used to service bank loans at par. As their funds became available, many depositors withdrew. Holders of savings deposits - typically people of modest means - feared they could lose their holdings if they waited. Between April and December, some US\$465m (about 3.2 per cent of 1999 GDP) in checking and savings deposits, both on- and off-shore, were unfrozen. About a third of these deposits are estimated to have been fully withdrawn from - i.e., not deposited back in -- the banking system, fuelling capital flight and exchange-rate depreciation. ${ }^{13}$

The Central Bank had little choice but to provide the banks liquidity support. From December 1998 through 1999 the Treasury issued about US $\$ 1.6 \mathrm{~b}$ in bonds to recapitalize banks that were still open and to finance payment of guaranteed deposits of banks that had been closed. Banks recapitalized in this form used a large proportion of the bonds in liquidity operations with the Central Bank (rediscounting them or engaging in repurchase operations). The Central Bank acquired some US $\$ 1.2 \mathrm{~b}$ (on the order of 10 per cent of 1999 GDP) in bonds. The monetary base grew 136 per cent over $1999,{ }^{14}$ with the liquidity operations accounting for more than all of this. The expansion would have been even larger, but the Central Bank sterilized about a quarter of the liquidity support it provided by selling its own interest-bearing obligations. These were acquired mainly by a small group of "better" banks that had excess resources as a consequence of depositors' "flight to quality" within the banking system.

By the end of 1999, virtually all checking and savings accounts had been unfrozen. Unfreezing of time deposits was due to commence in mid-March' 2000 (deposits were to be freed a year from their original maturity date). Well before the end of 1999, however, the authorities concluded that they would have to limit the unfreezing of time deposits, because banks would have only a fraction of the resources needed to meet withdrawal demand. Between the banks' on- and off-shore offices, ${ }^{15}$ about

\footnotetext{
${ }^{12}$ Since loan classification is subject to conventions and judgments, the magnitudes should be considered suggestive rather than precise.

${ }^{13}$ In November 1999, the authorities came under intensified pressure when Ecuador's Constitutional Tribunal ruled that the freeze had been unconstitutional, and had to be reversed as soon as possible.

${ }_{14}^{14}$ The base grew at annualized 101 and 522 percentage rates respectively in the last two quarters of 1999.

${ }^{15}$ Off-shore deposits were also legally frozen, and could not legally be withdrawn from within Ecuador. The authorities in some overseas jurisdictions did not recognize the freeze.
} 
US $\$ 2.2 \mathrm{~b}$ in deposits were due for release from March through June 2000 . Heavy withdrawals would either thrust banks into failure, with contagion effects throughout the system, or oblige the Central Bank to provide liquidity credit and create money, intensifying exchange-rate depreciation, inflation, and capital flight. In late 1999 the authorities began formulating schemes under which deposits could be partially paid out in Treasury bonds or in new bank certificates of deposit with extended terms (see Section 6).

Oil-export prices and earnings recovered during 1999 (see Figure 10), offsetting declining non-oil exports. Meanwhile, recession, exchange-rate depreciation and lack of bank credit brought about a 50-per-cent drop in merchandise imports compared with 1998. As a result, the current account swung from an 11-per-cent-of-GDP deficit in 1998 to a surplus exceeding 6 per cent of GDP in 1999 (see Figure 13), a strikingly large "adjustment." The overall 1999 non-financial public deficit reached 6 per cent of GDP, about the same as in 1998. Diminished revenue from domestic motor-fuel sales offset higher oil-export revenue: in July 1999 the Government froze domestic motor-fuel prices to settle a strike by transport workers. The recession reduced non-oil tax receipts and the exchange-rate depreciation forced up interest charges. With the recovery of oil earnings, the primary surplus rose to 3.2 per cent of GDP (compared with a 0.7 -per-cent deficit in 1998).

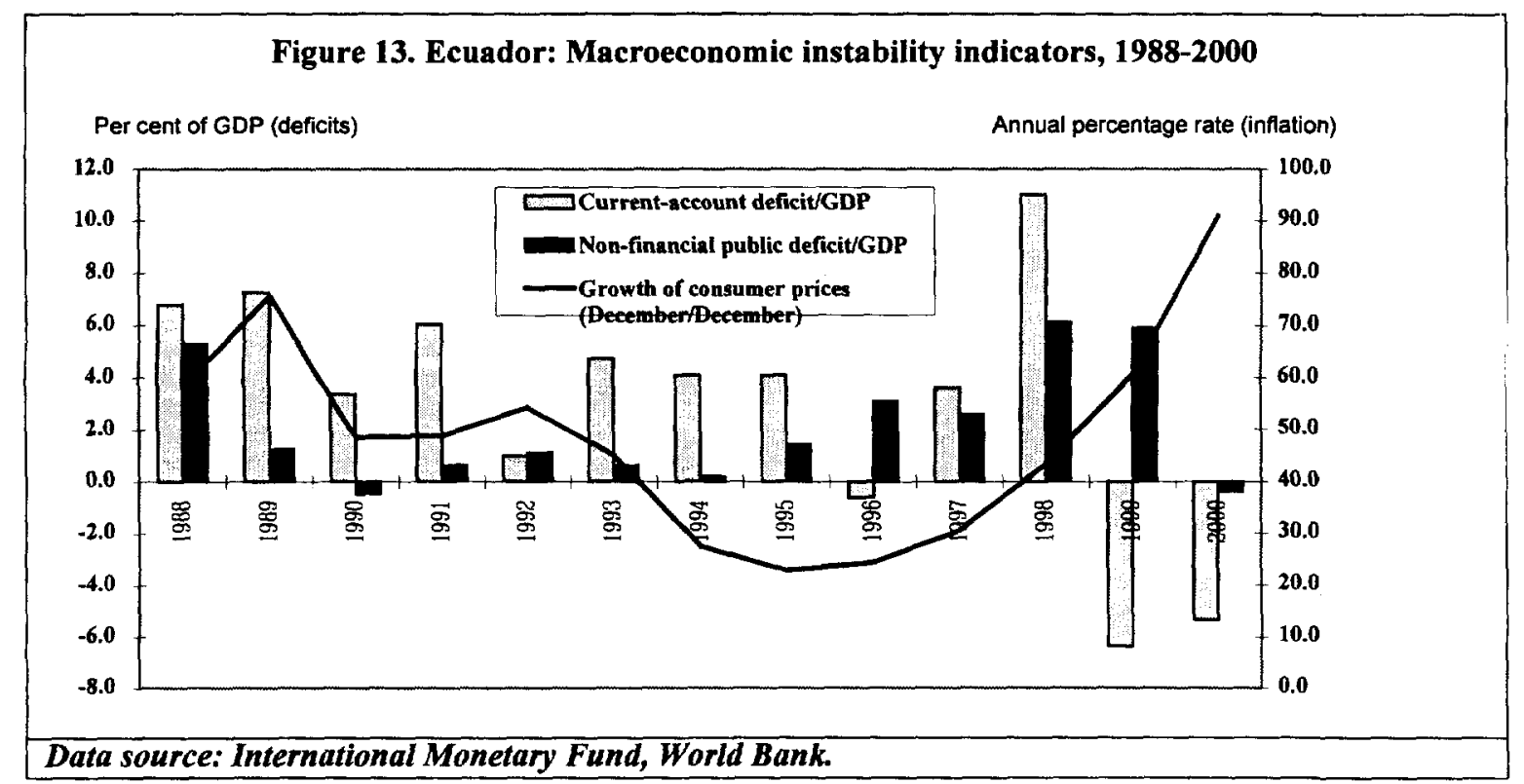

Even before the onset of the crisis the Government had sought support from the IMF, World Bank, IDB, and Andean Development Corporation (CAF). The Government had initiated discussions with the IMF on a stand-by program almost immediately after taking office in August 1998. In late 1998 the four institutions sent technical missions to advise on banking-sector policy. Discussions with the IMF broke off in late 1998 when the income tax was suspended, but then resumed and became increasingly urgent as the crisis deepened. During 1999, the four institutions worked closely together and with the 
Government, focusing on the banking system. They were unable, however, to reach agreement with the authorities on a program. Several times over the course of the year the IMF and Government nearly agreed on a stand-by program, even signing a letter of intent in late September 1999, but the Congress failed to approve tax measures the IMF deemed essential. (The IMF and Government reached agreement in April 2000, after the dollarization law was approved.)

The crisis took on an additional dimension in late August 1999 when the Government withheld interest due on Brady bonds and called on bondholders to discuss relief. Over the month-long period before bondholders could take legal action or request payment from collateral, however, the Government could find no way to begin discussions (Brady bonds were designed to make coordinated negotiations difficult to organize). At the end of September, the Government announced that it would pay interest only to holders of uncollateralized bonds, and suggested that other bondholders request the collateral. Bondholders, many of whom considered it wrong to treat one class of creditor preferentially in a default situation, chose instead to accelerate the principal. This activated cross-default clauses, which thrust Ecuador effectively into default on all its external bonds (US\$6.5b out of total public external debt of US\$13b). In the weeks following, the Government succeeded in opening a dialogue with selected bondholder representatives, but could not begin serious negotiations (although bondholders did refrain from litigation). Bondholder representatives were unwilling to work on a deal on which they would have to stake their own credibility. (Later, in August 2000, the Government got around this obstacle by making an exchange offer directly to bondholders, who accepted new bonds against the Brady bonds at 60 cents on the dollar.)

Figure 14. Ecuador: Interest rates: Sucre, dollar deposit reference rates; interbank rates (annua] percentage rates)

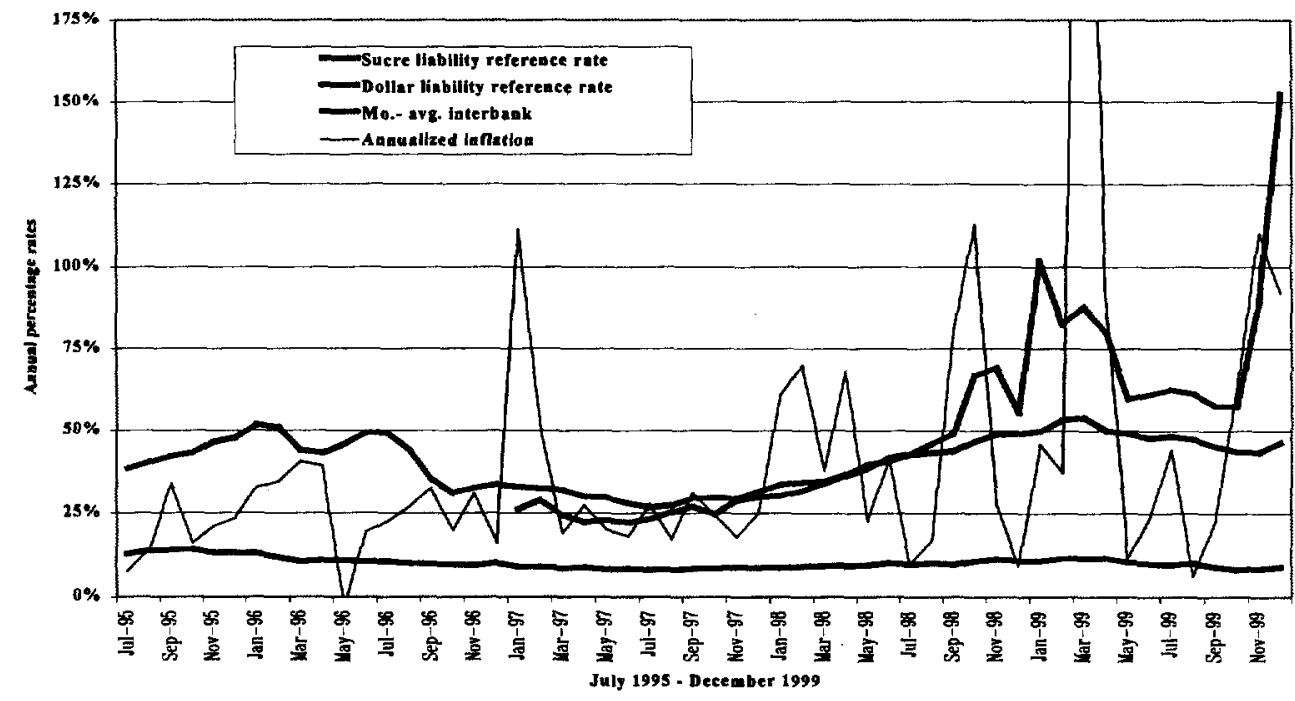

Data source: International Monetary Fund, World Bank. 
Toward the end of 1999 the heavy monetary issue, along with intensifying withdrawal demand, generated overwhelming pressure on the price level and exchange rate. Late in November 1999, with the exchange rate depreciating rapidly, the Central Bank announced that it would tighten policy -- in particular, no longer automatically provide banks liquidity credit nor try to moderate interbank interest rates. This change had revealing consequences. As expected, interbank interest rates surged (see Figure 14). Throughout the year, the Central Bank had been absorbing resources through openmarket operations in its own one- and two-week instruments, and so had taken on a large debt of its own. Its own interest bill had become a significant source of monetary expansion. The soaring interest rates resulting from the tight policy now served, perversely, to increase the rate of monetary expansion. It was all too evident that the Central Bank had lost the capacity to manage the money supply and the exchange rate. Financial markets reacted accordingly: during the first week of January the exchange rate went into apparent free fall, precipitating the decision to dollarize.

From this account it is clear that the banking system's semi-dollarization played a central role in the crisis dynamics. Once exchange-rate depreciation got under way, semidollarization made them more explosive, first because it directly increased the sucre equivalent of the money supply's dollar component, and then because borrowers' unmatched positions meant that depreciation increased non-performing loans and reduced service payments. Once depositors realized that the banks were in difficulties, they increased withdrawal pressure - and, to the extent they withdrew from dollar accounts, exchange-rate depreciation swelled the sucre equivalent of what they could withdraw.

\section{Ecuador's approach to dollarization}

For several days after the initial announcement, it was unclear whether "dollarization" would mean (i) a conventional fixed exchange rate; (ii) "loose" convertibility, under which the Central Bank could carry out a broad range of transactions so long as it maintained full foreign-exchange backing for all local-currency issues at a fixed exchange rate, (iii) "strict" convertibility, under which the only allowable Central Bank transactions would be purchase and sale of foreign exchange at a fixed exchange rate; (iv) complete substitution by the dollar for the sucre, but with the Central Bank retaining some functions; or (v) complete substitution of the sucre by the dollar, with the Central Bank closed and liquidated. After internal discussion and advice from foreign experts, the Government decided on the fourth of these alternatives. There would no longer be a domestic currency, but the Central Bank would operate as a limited liquidity regulator cum "lender of last resort," using allocated or borrowed foreign-exchange resources. Especially with time-deposit unfreezing just ahead, the authorities felt it was best that the Central Bank retain as much of these functions as possible. ${ }^{16}$

\footnotetext{
${ }^{16}$ Semantics are a problem here: a true "liquidity regulator" and "lender of last resort" presumably must be able to create money. The idea was that the Central Bank would be a limited entity, operating basically through the size of its foreign-exchange holdings, able to prevent minor problems from getting out of hand but unable to create money.
} 
The basic dollarizing legislation approved early in March 2000 was called the "Fundamental Economic Transformation Law." use part of its foreign-exchange holdings to repurchase the outstanding sucre stock (the Central Bank's total foreign exchange stock was nearly double the sucre currency stock); and also provided for adoption of the dollar as an official monetary unit. ${ }^{18}$ It also provided that legal accounting records would henceforth be maintained in dollars, with public contracts, tax assessments, and public accounts to be converted at the fixed rate. It directed the Central Bank to issue coins in denominations smaller than one dollar (as in Panamá, on a currency-board basis against foreign-exchange holdings). It specified that the Central Bank would continue providing commercial-bank clearing-house services, for which it would continue holding bank-reserve deposit accounts.

The Law reorganized the Central Bank into four "systems" with segregated balance sheets. In the first, foreign exchange holdings back an equal quantity of old sucres and new small-value coins. In the second, foreign-exchange holdings stand behind an equal stock of bank reserve deposits and Central Bank "stabilization bonds." In the third, the Central Bank's remaining foreign-exchange holdings, Treasury bond holdings, and holdings of repurchase agreements stand behind the Central Bank's external obligations (including those to the IMF), the public sector's deposit accounts, and Central Bank stabilization (open-market) bonds. The foreign exchange in this account would henceforth be considered "available" gross international reserves, since amounts held in reserve against coins and against banks' reserve deposits would be unavailable for external transactions. (Under dollarization, of course, private entities would not need to purchase foreign exchange from the Central Bank.) Finally, the fourth balance sheet comprises the Central Bank's remaining assets and liabilities and its accumulated capital position.

That is, the Central Bank's foreign exchange is assigned first to back coins and banks' reserve deposits, then all other liabilities. Some of these other liabilities, particularly external obligations (including those to the IMF), are long-term. The Treasury's deposit balance at the Central Bank is a sight account, however. Net withdrawals from this account imply direct reductions in the country's internationalreserve position. Table 3 shows the four balance sheets as of March 10, when the system commenced, and then at the ends of the four quarters of 2000. ${ }^{19}$ The withdrawal of sucres and introduction of coins can be seen in the progress of the first balance sheet. The virtual stagnation of the second balance sheet is indicative of the slow pace of recovery in banking-system operations over the course of the year (see Section 6). The table also shows the increase over the year in the overall international-reserve position

\footnotetext{
${ }^{17}$ Informally, the Law came to be called the "Trolleybus Law" - i.e., more encompassing than an

"omnibus" law and moving at high speed on rails.

${ }^{18}$ The sucre retains de jure status under the Constitution.

19 The monetary base is defined as the sum of the monetary emission and bank reserve deposits. It is not comparable with the monetary base before dollarization, since currency in circulation after dollarization consists of dollar currency not issued by the Central Bank.
} 
and in the third system's "available" reserves, deriving basically from the current-account surplus and credit from multilateral lenders.

Table 3. Ecuador: The Central Bank's four balance sheets, March 10 - December 31, 2000

$$
\text { USS million: }
$$

(1) Exchange system (net):

Assets:

International reserves $(\mathrm{A})$

Liabilities:

Monetary emission *

Sucres

Small-denomination coins

(2) Financial reserve system (net):

Assets:

International reserves (B))

Liabilities:

Reserve deposits

Monetary stabilization bonds

(3) Main operations system (net):

Assets:

International reserves (C))

Repurchase operations

Treasury obligations

Liabilities:

Non-financial public-sector deposits

Private deposits

Central-bank term obligations

(4) Other operations system (net):

Assets **

Liabilities and capital **

Memorandum:

International reserves

Monetary base
10-Mar-00

31-Mar-00

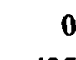

425

425

$-425$

$-425$

$-425$

0

0
299

299

$-299$

$-287$

$-12$

0

821

141

38

642

$-821$

$-512$

$-26$

$-283$

0

1627

$-1627$

865

712
0
425

425

$-425$

$-425$

$-425$

0

0
216

216

216

$-216$

$-206$

$-10$

0

849

138

138
36

675

-849
-386

$-386$

$-23$

$-440$

0

1626

$-1626$

779

631
30-Jun-00

30-Sep-00

31-Dec-00

* Small coins and sucres still outstanding.

** Includes capital positions in international organizations and collateral for interest on Brady bonds.

*** Includes exchange adjustment and provisions.

The dollarization Law allows Central Bank "liquidity" operations with banks, including transactions in stabilization bonds with commercial banks (under its second system) and repurchase operations (under its third system). The Central Bank's foreignexchange resources and liabilities to external lenders and to the Treasury will limit its scope to do such operations, however. The Central Bank will be able, in effect, to carry out some "recycling" operations, accepting resources from banks with more liquidity than they require and on-lending them to illiquid banks. Such recycling matters because, as 
noted above, depositors have been observed to "fly to quality," transferring deposits from weaker to better banks. To supplement the Central Bank's capacity to manage short-term liquidity problems, a separate Liquidity Support Fund was set up outside the Central Bank, capitalized through a US $\$ 70 \mathrm{~m}$ loan from the CAF. Banks would be required to place deposits with the Fund amounting to one per cent of their deposit base, a supplemental reserve requirement (on top of the present eight per cent).

Under its new structure the Central Bank gives up most, but not all, seigniorage earnings. ${ }^{20}$ To the extent it receives interest on foreign-exchange holdings, it earns something like a seigniorage flow, although this will be offset by any interest the Central Bank pays for borrowed funds.

The dollarization legislation also tightened financial-system regulation, clarifying rules defining capital adequacy and regarding the time commercial banks would have to remedy capital deficiencies. Accompanying regulations further provided for gradual adaptation of international standards for commercial-bank accounting, to be used to gauge compliance with Basel norms.

A transitory disposition in the Law provided for a one-time reduction in interest rates on existing sucre and dollar-denominated financial assets. For contracts outstanding on or after January 11, asset rates were reduced to 16.82 per cent for assets and 9.35 per cent for liabilities (contracts already at lower rates would retain their original rates). The Law also provided for conversion of sucre interest rates on outstanding loans at the moment of dollarization (the "desagio" table). In something of a reversal of financial liberalization, the Law subjected interest rates to a usury ceiling, to be set periodically by the Central Bank as a "risk" spread over LIBOR, up to 1.5 times the banking system's average lending rate (the so-called "reference" rate calculated by the Central Bank from data obtained from the banks). Although this was intended to prevent banks from engaging in dangerous high-interest-rate practices, many observers argued that existence of a usury ceiling would discourage would-be financial-system entrants. (In general, to prevent banks from engaging in dangerous interest-rate competition, forceful prudential regulation -- requiring banks to show that high-interest operations are safe enough, and perhaps setting capital requirements if necessary -- is a better approach than usury ceilings.) In July 2000 the Government issued a "clarification" to the effect that the usury limit would be exactly (i.e., not up to) 1.5 times the banking system's prevailing average lending rate.

The dollarization legislation and subsequent regulations also provided for reprogramming of private debt to financial institutions. The 800,000 -odd debtors who each owed less than US\$50,000 in all to the financial system were authorized to reprogram it, under standard formulas applicable to broad categories of debt (credit cards, mortgages, etc.) for up to seven years. The Law and subsequent regulations set a legal framework to enable the several hundred debtors owing more than US $\$ 50,000$ to renegotiate their loans. The Government hoped this would help banks and businesses to

\footnotetext{
${ }^{20}$ For present purposes, the seignorage flow is understood as the earnings flow a monetary authority receives on assets held against its monetary issue, less any interest paid on that monetary issue.
} 
put the crisis behind them. Since the Law was approved, however, the Government has come under political pressure to make the debt reprogramming compulsory and generalized, for larger as well as for smaller debtors, and to reduce the interest charges. The Government has resisted, hoping to limit reprogramming of large loans that are still viable, to ensure that banks maintain adequate cash inflows. (At this writing, however, although the smaller loans have been reprogrammed, only a few of the larger loans have been reprogrammed.)

Recognizing that the success of dollarization depends on structural reform beyond the monetary and banking system per se, the dollarization law approved in March and follow-up legislation approved in September 2000 (the so-called "Second Trolleybus Law") incorporated various structural-reform provisions. ("Success" refers here to whether economic performance improves, not to whether the authorities simply succeed in dollarizing.) The reforms included changes to expedite privatization of the telecommunications and electricity sectors and to open the hydrocarbons sector to private participation, as well as some "flexibilization" of formal labor-market restrictions.

(Section 7 returns to the structural-reform theme.)

\section{Transition issues}

Over 2000 , policy-makers had to deal with several implementation problems, including (a) unfreezing of time deposits; (b) the price-level increase resulting from the sucre's severe undervaluation; (c) adjustment of motor-fuel, electricity, and cooking-gas prices, along with wages; and (d) practical difficulties for people unfamiliar with dollar currency. This section discusses these issues.

Macroeconomic conditions during 2000 were relatively favorable for the transition. Surging world oil prices (see Figure 10) lifted export earnings, compensating for the sluggish performance of other commodity exports. (Sector-specific problems affected many commodity exports: disease afflicted shrimp exports, for example, while banana exports had market-access problems.) Strong oil-export revenues (accounting for nearly half of total government revenue) and steady enough tax performance afforded breathing space for the fiscal accounts. Meanwhile, the depreciated real-effective exchange rate and sluggish economic performance -- real GDP growth was only 1.9 per cent in 2000, and important manufacturing and construction sub-sectors continued to decline -- kept imports low. The continuing strong current-account surplus helped the Central Bank accumulate foreign exchange: even with the purchase of sucres from circulation, the Central Bank's total holdings ended December 31 at about US $\$ 1.1 \mathrm{~b}$, an increase from US\$865m on March 10 .

Lending by multilateral institutions during 2000 also helped shore up the Central Bank's foreign-exchange base. In April 2000, after more than a year of discussions and negotiations, Ecuador secured a twelve-month, US\$304m IMF stand-by arrangement. The first of six scheduled tranches was released immediately. The IDB disbursed tranches of several sectoral adjustment loans originally approved in 1994 but delayed since then for various reasons. In June 2000 the World Bank approved a US\$150m 
structural-adjustment loan with conditionality covering comprehensive tax reform, public-sector financial management, financial-sector reform, and social-sector expenditure protection. It also approved a US\$10m Financial Sector Technical Assistance Loan. In June the IMF approved disbursement of the second tranche of its stand-by program, and then in September approved release of the third tranche. ${ }^{21}$ Thereafter, however, the IMF became concerned about the slow pace of structuraladjustment and tax reform, and did not release the next tranche until June 2001.

When they announced dollarization, the authorities' largest concern was that banks would have inadequate resources to cope with the time-deposit unfreezing due to commence in mid-March 2000. Accordingly, they also announced that no more than US $\$ 4,000$ would be made available in cash from each time-deposit account. The remainder was to be provided in the form of three- to seven-year marketable Treasury bonds, which banks would purchase from the Treasury with their own promissory notes. The bonds would take deep discounts, but could be used to pay taxes and service debt to banks at par. In the weeks leading up to the start of the unfreezing process, however, the state prosecutor raised legal objections to this use of Treasury bonds. The authorities decided then that, for deposit balances in excess of US $\$ 4,000$, depositors would receive longer-term certificates of deposit from the banks instead of Treasury bonds.

Release of time deposits commenced on March 13. To the relief of all concerned, banks generally succeeded in persuading depositors not to withdraw. Deposits actually increased somewhat over the year. Several factors contributed in some degree to this success. One is that in early March 2000 the IMF, World Bank, IDB and CAF made a joint statement, timed to buttress depositor confidence, that they would provide financial support totaling US $\$ 2.2 \mathrm{~b}$ over 2000,2001 , and 2002 . Another is that banks themselves carried out effective marketing campaigns. Dollarization may have persuaded many depositors that circumstances were changing for the better, and that the end of the dualcurrency system would make banks safer. The rulings by the Constitutional Tribunal and the state prosecutor's stand may also have contributed to depositor confidence. The unpopularity of the freeze and the fact that the President who had done it had been forced from office diminished the likelihood that anything similar could ever happen. Finally, depositors may have reasoned that the withdrawal limit would help ensure that banks had adequate liquidity. The Central Bank did not have to provide liquidity support to banks over the course of the unfreezing process. Banks able and willing to do so to were permitted to make the full amounts of deposit balances available. Foreign-owned banks and certain smaller banks did so, although not the large banks under AGD control.

High inflation has turned out to be a more serious transition problem. The main cause was the deeply depreciated exchange rate at the moment of conversion (see Figure 3), which implied that prices would have to rise to restore parity with world prices. Consumer prices rose 91 per cent over 2000 (compared with 60.7 per cent over

\footnotetext{
${ }^{21}$ Funds borrowed by the Central Bank from the IMF increase both the Central Bank's foreign-exchange reserves and its liabilities to the IMF. Funds borrowed by the Government from multilateral institutions are deposited by the Government in its Central Bank account, and so also increase the Central Bank's foreignexchange balances, but increase the Government's - not the Central Bank's - foreign-exchange liabilities.
} 
1999). One suggestive calculation is that prices would have had to rise about 130 per cent for the year as a whole to bring the real-effective exchange rate into line with the 1997-1999 average by December 2000 (trading partners' inflation was about @3 3 per cent). To be sure, the appropriate real-effective exchange rate may not be anything like the 1997-1999 average, particularly after the changed circumstances brought about by dollarization. Even so, it seems fair to conjecture that prices will reach parity and stabilize once they have risen by 120-140 per cent over their December 1999 level. ${ }^{22}$ Strictly speaking, this would be a one-time price-level increase, not a true "inflation." Over-shooting is possible: the real-effective exchange rate could then become overvalued. Deflation would then have to occur, or the price level would have to remain stable while world inflation took place, to induce real-effective depreciation. The "Hume" mechanism would presumably operate -- dollars would be "exported" in exchange for imported goods and services, the economy's dollar stock would shrink, and this would drag down the price level, producing real-effective depreciation. (Tradables prices in dollars would presumably be set externally, so it would be non-tradables prices that actually fell.) "Downward price stickiness" implies that deflation could take a painfully long time, however. As Argentina's recent experience illustrates, the realeffective exchange rate simply cannot adjust so rapidly under dollarization and convertibility as with floating or less firmly fixed exchange rates.

A closely related transition problem has been adjustment of motor-fuel, cookinggas, and electricity prices, as well as formal-sector wages. Motor-fuel prices had been frozen for a year in July 1999; the sucre price of household cooking gas had been fixed since September 1998 (see Figure 15); and electricity rate adjustment had lagged. Accumulated exchange-rate depreciation and inflation meant that these fixed prices implied forgone government and public-enterprise revenue amounting to several percentage points of GDP. Political and equity considerations implied, however, that energy-price adjustments would require simultaneous wage adjustment, which would, inter alia, affect public-sector staff expenditure. Real wages had been declining for months in real terms. (Figure 16, which shows the evolution of the real earnings of a private-sector worker earning the minimum wage and mandated complementary pay, shows the decline in real-wage levels over the course of the crisis.) Taken together, the adjustments involved three broad issues: (i) allocative efficiency (and international competitiveness); (ii) the non-financial public-sector finances; and (iii) social equity.

For the April 2000 IMF stand-by program, the Government promised to raise motor-fuel prices and wages in two steps, in July and October, and to increase the cooking-gas price by 40 per cent. The Government then reasoned that it should address the problem in one go, rather than face two periods of heightened social tension. On May 25, it announced 60- to 80-per-cent motor-fuel price increases. It decided not to raise the politically sensitive cooking-gas price, however, but instead raised prices of jet fuel and industrial oil derivatives by about 300 per cent. It also authorized 48- to 70-per-

\footnotetext{
${ }^{22}$ Deposit rates have been relatively steady at several percentage points over LIBOR. At the measured inflation rate, they are highly negative in real terms, but this is not a relevant indicator. The relevant opportunity cost would be external deposit rates, with a firmly fixed exchange rate. It would be impractical for a would-be depositor to speculate by purchasing a commodity bundle for subsequent sale.
} 
cent public-sector pay increases, and raised the monthly stipend it had been providing mothers of poorer families since September 1998 by 75 per cent. On May 31 it raised electricity-rates. If the price level had then stopped rising, these prices would have been more or less "in line." Unfortunately, however, the price rise continued, causing energy prices and formal-sector wage rates to lag in relative terms. In January 2001 the Government announced corrective increases. Widespread popular demonstrations ensued. The Government negotiated an agreement with demonstration leaders, under which, inter alia, it reduced the increase in the cooking-gas price from 100 to 60 per cent, promised that motor-fuel prices would remain unchanged for at least twelve months, and promised to maintain a dialogue with representatives of demonstrating groups.

Figure 15. Ecuador: Evolution of domestic motor-fuel prices (deflated by consumer prices; December $1999=100$ )

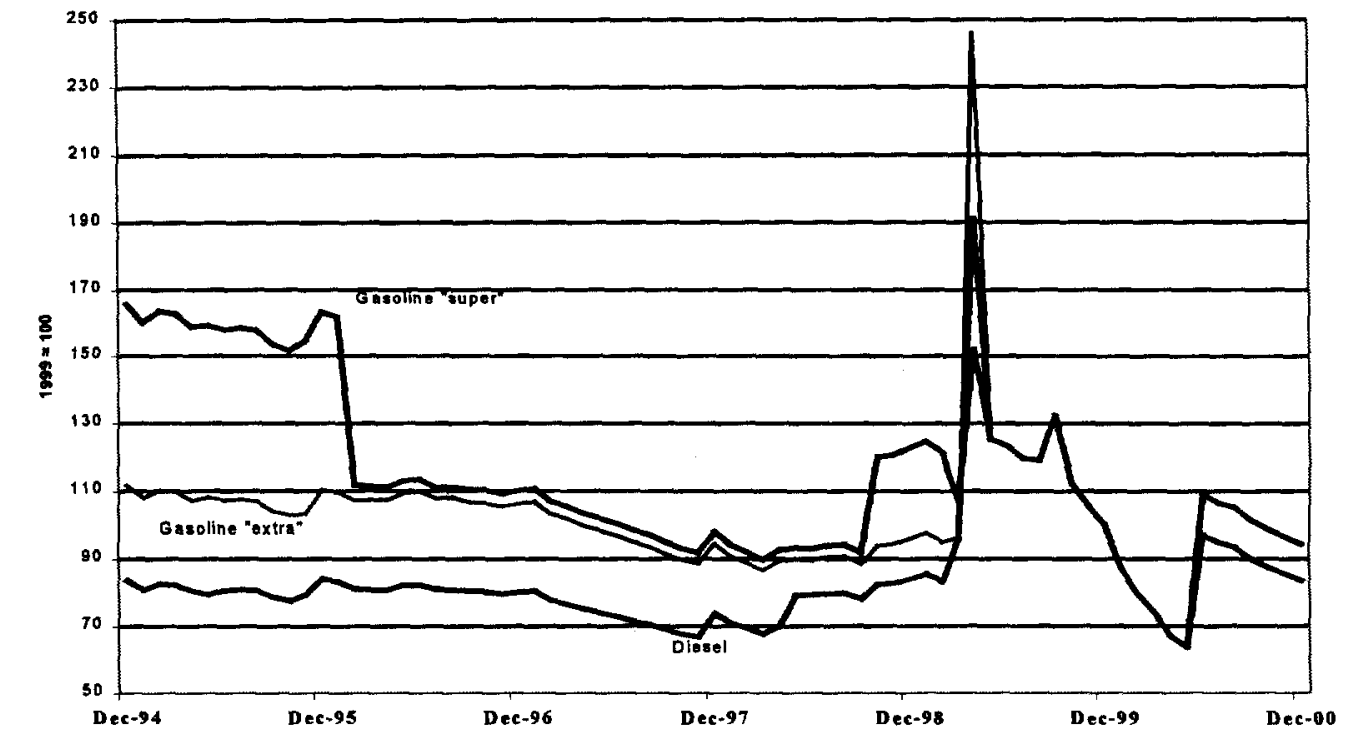

Data source: Central Bank of Ecuador.

The problem of the energy-price and wage adjustments is an aspect of a broader problem. As dollarization establishes price-level stability, prices and costs must find their way to jointly appropriate values, on the allocative, public-finance, and social-equity criteria. This convergence process is bound to be complicated, especially if key prices and costs are politically determined. Tradables prices would presumably move relatively rapidly to international parity values, but adjustment of non-tradables prices and factor costs is likely to involve intricacies. Overshooting adjustment is a potential danger: people will not know (or believe) that the once-and-for-all increase in the price level has reached parity, and should then cease. Labor leaders might argue that wage increases should reflect a likelihood of further price-level increase, as recently experienced. To the extent they secure such increases, they could delay economic revival, since labor costs would then become relatively high, affecting business competitiveness. 
Along with the financial-sector and price-realignment problems, some practical problems arose in the transition process. Many people experienced initial difficulty adjusting to using dollars (the fact that dollar bills are all the same color was a problem for illiterate people, for example), and the authorities had to carry out a publicinformation campaign. Shortages of small-denomination coins (see Associated Press 2000) were also a problem. Counterfeiting has occurred, although its extent is (by its nature) difficult to determine. All the same, by September 9, 2000, the date at which the dollar officially became Ecuador's legal currency, even people who still believed it had been a mistake accepted dollarization as irreversible.

Figure 16. Ecuador: Total remuneration received by a typical private-sector worker earning the minimum wage

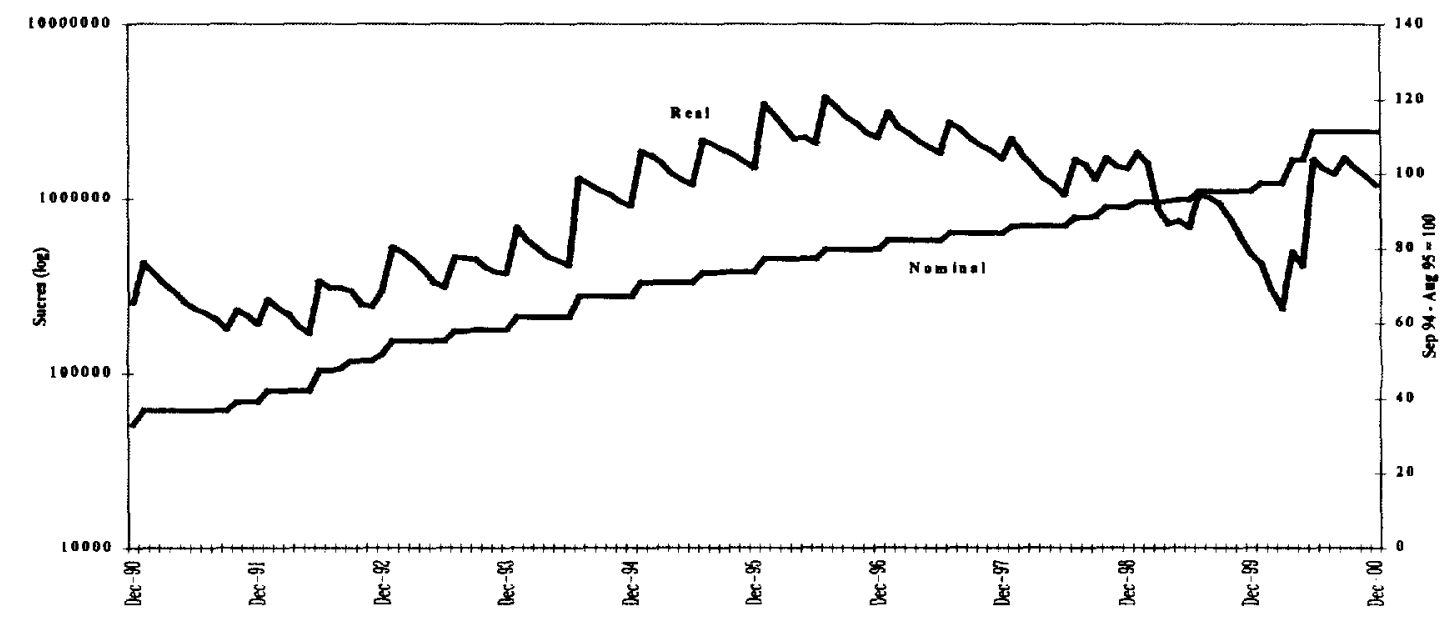

Data source: Central Bank of Ecuador.

\section{Longer-term prospects following dollarization}

Once the price-level increase is completed and subsides and prices and wages adjust, Ecuador can expect to experience dollarization's basic bargain: inflation should fall to the world rate, but exchange-rate depreciation will no longer be possible. A limited amount of something like money creation will be possible - for example, whenever the Treasury withdraws from its deposit account, dollars move from the Central Bank's vaults into circulation within the economy. Domestic credit creation will be tightly limited by the dollarization rules, however. The stakes for fiscal policy and banking regulation will therefore be higher than before. The basic deficit-financing options will be to (i) run down the Treasury's deposit account at the Central Bank, reducing foreign-exchange balances; (ii) contract additional external debt; (iii) sell public debt in domestic financial markets, which would pressure interest rates up (and perhaps attract foreign finance); and (iv) incur arrears. Banks experiencing solvency difficulties may require further 
recapitalization (possibly with Treasury bonds); but the Central Bank's capacity to provide support to banks sliding into liquidity difficulties will now be constrained.

Once the price level stabilizes, relative price relationships should become more certain. Tradables prices should be anchored by the relevant world prices, but even nontradables prices should become more stable. Double digit annual inflation previously meant that the real significance of any given wage increase or price adjustment was uncertain: higher or lower inflation following the change implied different ex-post income-distribution and relative-price outcomes. This uncertainty may actually have been helpful to social stability, making it possible to set relatively high nominal wage increases and then permit inflation to erode them. Dollarization and price stability reduce such ambiguity: nominal changes in wages and prices will have more reliable real consequences. This is positive on the criterion of transparency, but it raises the stakes in disputes among social groups regarding wage and price increases.

The end of the dual-currency system removes a fundamental impediment to stability and so to growth. Important obstacles to sustained growth remain, however. Ecuador's exposure to volatility and risk is an unavoidable consequence of its geography, although improvements in the economic structure can help mitigate their consequences for the fiscal and financial systems. The external debt remains a large problem, and policy-makers must continue to address it, through negotiation, improvement of terms where opportunities arise, and control of the public deficit. Debt service will continue to limit developmental expenditure, and uncertainties about debt management are likely to keep Ecuador's risk ratings relatively high for some time to come.

Ecuador's best hope of ensuring sustained longer-term growth lies in advancing its structural-reform agenda. Since the crisis began, progress has been limited, and the present "agenda" is still quite similar to the agenda going into the crisis (see Section 2). Public-sector finances are as vulnerable as ever to oil-revenue volatility; domestic energy subsidization remains politicized and untargeted; and non-oil taxation still requires integral reform. Stabilization of oil revenue is crucial. To help cope with oil-export revenue volatility, the Government plans to implement a stabilization fund, which would accumulate oil-revenue proceeds when prices are high and release them back to the Treasury when prices are low. Prioritization of investment projects, with lower-ranked projects carried on only when oil revenues are relatively high, could also help. ${ }^{23}$ The best approach to manage domestic oil-revenue volatility would be to set prices according to automatic adjustment formulas. Oil-derivatives prices were automatically adjusted from 1995 until January 1997, when a large adjustment, driven by exchange-rate depreciation, contributed to popular protests that forced an elected government from office. That system might have been more politically acceptable if it had incorporated "caps" to spread large adjustments over longer time periods. Frequent, small automatic adjustment of motor-fuel, electricity and cooking-gas prices, with mechanisms to spread out large adjustments over time, would help keep them at appropriate levels without "traumatic" increases. Elimination of the exchange rate removes one cause of large adjustments.

\footnotetext{
${ }^{23}$ Some observers favor using "windfall" export proceeds to pay down public debt, and to borrow when export proceeds decline. The government may be able to apply a combination of approaches.
} 
The tax-reform proposals the Government has been considering would set mutually appropriate rates and structures for the main non-oil taxes (value-added, tariffs, personal and corporate income, and excises); reduce tax earmarking; and reform and modernize provincial and municipal revenue bases. The Government hopes to increase the value-added rate, but it will not be easy to secure approval by the Congress.

In working out their overall approach to revenue, expenditure and debt management, policy-makers must aim for overall fiscal sustainability. In essence, their challenge is to bring about a fiscal structure in which expenditure on education, health, social-welfare and infrastructure remains adequate to meet poverty-reduction and development needs, while enabling the external and domestic debt stocks to decline gradually as percentages of GDP through deficit control. That is, revenue, expenditure and debt-management policies need to be planned out in consistency with one another. In mid-2000, when Ecuador made its bond-exchange offer, many observers expressed concern about fiscal sustainability even with reduced debt service. As matters now stand, fiscal sustainability comes down to a question of how lucky Ecuador turns out to be with oil-export prices. That is, until policy-makers carry out the reforms needed to stabilize revenue and expenditure, the fiscal accounts remain vulnerable.

One area of structural reform in which Ecuador has progressed since 1998 has been implementation of modern fiscal-management systems, an essential but longdelayed change. The authorities have also begun implementing a crucial reform of the Finance Ministry, equipping it institutionally and organizationally to carry out more effective policy-making and improving its financial-management capacities. Although it has thus far not been possible to find buyers for the telecommunications and electricity enterprises, they have been reorganized along commercial lines, and considerable progress has been made in setting up regulatory entities. The Government is working on a social-security reform proposal, and debate continues on decentralization.

Longer-term growth also depends on Ecuador's success in establishing a safe, stable, efficient financial system. In broad terms, three things must be accomplished. One is to wind up the crisis -- i.e., sell the banking assets now held by the AGD, and restructure private-sector debt to commercial banks in such a way that viable enterprises can resume productive activity while banks maintain an adequate cash flow.

(International experience suggests that this kind of exercise is difficult anywhere, and especially so for developing economies.) The second is to strengthen banking supervision, to ensure that banks operate safely, or, if not, that problems are rapidly detected and resolved. Reforms under implementation in the context of the IMF and multilateral lending include stronger standards for income recognition, loan classification, and provisioning; adoption of enhanced Basel standards for bank capital; upgrading of the Banking Superintendency's and AGD's technical capabilities; and improved management of banks now under public stewardship. Banking supervisors will need to monitor liquidity and capital adequacy carefully, and be prepared to intervene and force rapid corrective action. The AGD has been structuring itself slowly, and after 
almost two years in existence has made only limited progress toward effectively managing, let alone divesting, the banking assets it controls.

The third is to find a way to deal with the reality that banks working in Ecuador are, perforce, exposed to the country's wide range of contingencies. Depositors are likely to seek risk premia on deposit rates at banks whose portfolios are concentrated in Ecuador, on the view that these portfolios are riskier than those in other economies. They will prefer banks with high capitalization levels, obliging banks to operate with higher intermediation costs on top of high funding costs. (Subject to the regulatory norms, banks will have to determine their optimal capitalization levels: high capitalization presumably reduces funding costs but requires higher intermediation spreads to maintain.) Ecuadorian borrowers are therefore likely to face relatively high borrowing costs, potentially constraining longer-term growth. Appropriate financial-sector reform, along with vigorous, high-quality banking supervision, can help relieve but probably not entirely solve this problem. One approach would be to seek ways to "dilute" the risk of loan portfolios concentrated in Ecuador into larger, "world-dimension" capital bases. By acquiring shares in Ecuadorian banks, foreign banks would effectively swing their larger capital bases behind Ecuadorian risk. Depositors should then be willing to accept lower interest rates, and to this extent lending costs should diminish. In return, however, the foreign banks are likely to seek relatively high intermediation spreads, to generate profits to compensate them for bearing the risk and also to help shore up their capital bases in readiness for contingencies. Alternatively, Ecuadorian financial institutions might be persuaded to purchase explicit or implicit "insurance" from foreign entities.

The Central Bank will have to define its precise role in the new context. It will take time for policy-makers to gain a clear sense of how to manage liquidity with limited instruments and tight constraints. For banks seeking liquidity support, the Central Bank will have to ensure that they are only illiquid, not insolvent, and that its resources would make a difference, not just be "bad money after good." Even then, it must carefully determine how far it can lend from its own resource base, given other banks' or the Treasury's potential needs. In this framework, the Central Bank's resources could prove insufficient to keep a large bank from failing.

\section{Conclusions: lessons and speculations}

In retrospect, Ecuador had little choice but to dollarize when it did. The authorities had lost the capacity to control the money supply and, hence, the sucre's dollar or purchasingpower value. By dollarizing, they gave up no policy instruments they had not in reality already lost. Dollarization is perhaps best regarded as a structural reform ending an unmanageable dual-currency system. Once price-level parity is reached, prices should stabilize, and this in turn should enhance growth prospects. Even so, Ecuador's "fundamental" problems remain, and must be addressed. The public-debt burden remains debilitatingly high, even after the reduction through the bond exchange in August 2000. The structural-reform agenda remains large. Much of it involves changes to mitigate the vulnerability of the fiscal accounts and banking system to Ecuador's unusually broad array of contingencies. 
Many Ecuadorians hope that, at least over the longer term, dollarization will bring about economic performance like Panamá's. Panamá has been dollarized since 1904, and has no central bank. Its economic growth and stability since the 1970 s have been far superior to Ecuador's (see Moreno 1999). It is important to remember, however, that Panamá is not subject to the kinds of natural hazards Ecuador faces. Nor does it depend on commodity exports to volatile international markets: Panamá's foreign-exchange earnings derive mainly from the Canal, Free Trade Zone re-exports, and service income from international banking operations, none of which are subject to unusual volatility. Panamá's only significant instability in recent decades has arisen from instances of confrontation with the United States. At such times, the foreign capital bases of the international banks operating in Panamá have fulfilled what amounted to lender-of-lastresort functions for the banking system (see Moreno 1999). This may be Panamá's most relevant lesson for Ecuador: to make dollarization work well over the longer term, it needs to ensure solid international backing for its banking system.

\section{REFERENCES}

Acosta, Carlos Albert (2000). "La trampa de la dolarización." (Contrapunto: Boletín Mensual de la Red de la Sociedad Civil; Quito, Ecuador) (May) pp. 7-10.

Arteta, Gustavo (1999). “Opciones cambiarias para el Ecuador: El dilema de la elección" (CORDES: Quito, May)

Associated Press (2000). "Ecuador Struggles with U.S. Dollars" (August 14).

Banco Central del Ecuador (2000). “Dolarización” (http://www.bce.fin.ec/avisos).

Banco Central del Ecuador (2000). Boletín Mensual," various issues.

Baliño, Tomás J. T., Charles Enoch, et al (1997). "Currency Board Arrangements: Issues and Experiences." (Internatiional Monetary Fund Occasional Paper 151), August.

Bayas, Santiago and Eduardo Somensatto (1994). "Programa de sucretización ecuatoriano: historia de los efectos monetários de la conversión de la deuda externa del sector privado." Cuestiones Económicas (Banco Central del Ecuador: Quito, Ecuador) No. 23 (December).

Beckerman, Paul (1986). "Inflation and Dollar Accounts in Peru's Banking System, 1978-1984," World Development, August, Vol. 15, No. 8, pp. 1087-1106.

\section{continues}




\section{REFERENCES (continued)}

Berg, Andrew and Eduardo Borensztein (2000). "Full Dollarization: The Pros and Cons," International Monetary Fund, Economic Issues No. 24 (December).

Calvo, Guillermo and Carlos Végh (1992). "Currency Substitution in Developing Countries: An Introduction." Revista de Análisis Económico, Vol. 7 No. 1, pp. 48-57.

Calvo, Guillermo (1999). “On Dollarization.” (draft) (April)

Calvo, Guillermo (2000). "Capital Markets and the Exchange Rate with Special

Reference to the Dollarization Debate in Latin

America"(http://www.bsos.umd.edu/econ/clecalvo.htm) (April)

Carrasco V., Carlos Marx (1998). Ecuador y el Consenso de Washington: La Hora Neoliberal (Cuenca, Ecuador).

Clements, Benedict and G. Schwartz (1992). "Currency Substitution: the Recent Experience of Bolivia (IMF Working Paper: Washington, DC).

El Comercio, Quito daily newspaper (various issues)

Enoch, Charles and Anne-Marie Gulde (1998). "Are Currency Boards a Cure for all Monetary Problems?," Finance and Development, Vol. 35 (December) pp. 30-43.

Fernando-Arias, Eduardo and Ernesto Talvi (1999). "Devaluation or Deflation?

Adjustment Under Liability Dollarization" (October).

Gomis Porqueras, Carlos Serrano, and Alejandro Somuano (2000). "Currency

Substitution in Latin America: Lessons from the 1990s" (World Bank Policy

Research Working Paper 2340: Washington, DC), May.

Government of Ecuador (2000). Letter of Intent for the International Monetary Fund Standby Program (http://www.bce.fin.ec/avisos/intent_fmi.html) (April)

Gulde, Anne-Marie (1999). "The Role of the Currency Board in Bulgaria's Stabilization" (IMF Policy Discussion Paper: Washington, DC), April.

Jaramillo, Fidel (1994). "Ecuador: Estabilización, ingreso de capitales externos y conflictos de politica macroeconomica." (Multiplica working paper: Quito, Ecuador (April).

\section{continues}




\section{REFERENCES (continued)}

Kopits, George, E. Haindl, E. Ley, and J. Toro (1999). "Ecuador: Modernización del Sistema Tributario. (Washington, DC: International Monetary Fund) (November)

Mancheno, Diego, J. Oleas, and P. Samaniego (1999). “Aspectos teóricos y prácticos de la adopción de un sistema de convertibilidad en el Ecuador." Notas Técnicas, Banco Central del Ecuador (Quito, Ecuador).

Moreno, Juán Luís Villalaz (1999). "Lessons from the Monetary Experience of Panamá: A Dollar Economy with Financial Integration." Cato Journal, Vol. 18 No. 3 (winter).

Rojas, Mónica (1998). "Dolarización en Ecuador: Economía 'verde'... pero no por lo ecológico. "Gestión (Quito, Ecuador) December, pp. 25-27.

Savastano, M. (1996) "Dollarization in Latin America: Recent Evidence and some Policy Issues." International Monetary Fund Working Paper (January).

El Universo, Guayaquil daily newspaper (various issues) 


\section{Policy Research Working Paper Series}

\section{Title}

WPS2628 Monopoly Power and Distribution in
Fragmented Markets: The Case of

WPS2629 Bridging the Digital Divide: How Enterprise Ownership and Foreign Competition Affect Internet Access in Eastern Europe and Central Asia

WPS2630 Parallel Imports of Pharmaceutical Products in the European Union

WPS2631 Pension Reform in Hungary: A Preliminary Assessment

WPS2632 Human Capital and Growth: The Recovered Role of Education Systems

WPS2633 Bank Privatization in Argentina: A Model of Political Constraints and Differential Outcomes

WPS2634 Chile's Regional Arrangements and the Free Trade Agreement of the Americas: The Importance of Market Access

WPS2635 Optimal Use of Carbon Sequestration in a Global Climate Change Strategy: Is There a Wooden Bridge to a Clean Energy Future?

WPS2636 Processes, Information, and Accounting Gaps in the Regulation of Argentina's Private Railways

WPS2637 Technical Efficiency Gains from Port Reform: The Potential for Yardstick Competition in Mexico

WPS2638 On Financing Global and International Todd Sandler Public Goods

WPS2639 Public Policy toward Nongovernmental William Jack Organizations in Developing Countries

WPS2640 Where Has All the Foreign Investment Harry G. Broadman Gone in Russia?
Date

June 2001

Rinku Murgai

Saeed Ur Rehman

George R. G. Clarke

July 2001

Mattias Ganslandt

Roberta Rocha

Dimitri Vittas

Sébastien Dessus

George R. G. Clarke

Robert Cull

Glenn W. Harrison

Thomas F. Rutherford

David G. Tarr

Franck Lecocq

Kenneth Chomitz

Javier Campos-Méndez

Antonio Estache

Lourdes Trujillo

Antonio Estache

Marianela González

Lourdes Trujillo
July 2001

July 2001

July 2001

July 2001

July 2001

July 2001

July 2001

July 2001

July 2001

July 2001

July 2001
Contact for paper

P. Kokila 33716

P. Sintim-Aboagye 37644

L. Tabada 36896

L. Gross

37030

K. Mazo 39744

P. Sintim-Aboagye 37644

L. Tabada 36896

V. Soukhanov 35721

G. Chenet-Smith 36370

G. Chenet-Smith 36370

S. Kpundeh

H. Sladovich 37698

S. Craig 33160 


\section{Policy Research Working Paper Series}

\section{Title}

WPS2641 Is Russia Restructuring? New
Evidence on Job Creation and
Destruction

Author

Harry G. Broadman

Francesca Recanatini

Ilker Domaç

Kyles Peters

Yevgeny Yuzefovich
Contact for paper

S. Craig 33160

July 2001

A. Carcani 30241 